\title{
Molecular Diagnostics of Infectious Diseases
}

\author{
Malin Nygren
}

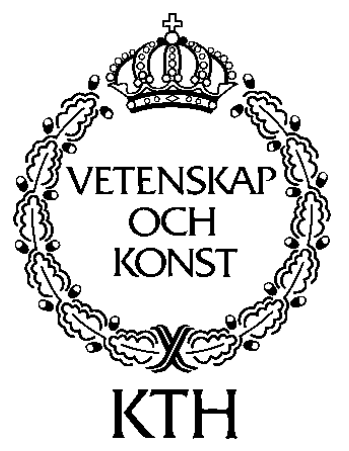

Royal Institute of Technology

Department of Biotechnology

Stockholm 2000 
Malin Nygren (2000): Molecular Diagnostics of Infectious Diseases. Department of Biotechnology, Royal Institute of Technology, KTH, Stockholm, Sweden.

ISBN 91-7170-504-X

\section{AbSTRACT}

In DNA-based diagnostics, the polymerase chain reaction (PCR) is the most widely used DNA amplification method. To enable both sensitive and specific detection of agents causing infectious diseases, the PCR needs to be combined with methods to prepare the clinical sample containing the genetic material of the pathogen. Furthermore, methods for detection and DNA sequence analysis of the PCR amplification products are needed. This thesis describes the development of integrated systems for detection, quantification and characterization of microorganisms.

An immunomagnetic separation (IMS) technique has been used to isolate Bordetella pertussis from nasopharyngeal aspirate samples. The post-PCR detection and typing of Bordetella spp. was performed by a combination of restriction enzyme analysis of the amplified pertussis toxin (PT) promoter region and a solid-phase colorimetric detection system; detection of immobilized amplified nucleic acid (DIANA). To investigate whether this approach could be used for reliable discrimination between the three Bordetella spp. infecting humans, the PT promoter region used for diagnostics was sequenced in 33 strains. To determine the DNA sequence of this polymorphic and repetitive region, a new technique, bidirectional pyrosequencing, was utilized. This procedure was used to resolve the sequence of this DNA region, which is able to form stable secondary structures in conventional Sanger DNA sequencing. A quantitative assay using competitive PCR and the DIANA detection technique was also developed, for quantification of $B$. pertussis in clinical samples.

By arbitrary PCR, a DNA sequence apparently specific for Vibrio cholerae O139 Bengal was isolated and characterized. A nested PCR assay was developed for sensitive and specific detection of $V$. cholerae O139 Bengal in clinical samples and in environmental water samples, where differentiation between $V$. cholerae O139 Bengal and $V$. cholera $\mathrm{O} 1$ is of epidemiological interest.

The magnetic separation approach was also used to capture human immunodeficiency virus (HIV-1) RNA from patient plasma. A nested reverse transcription (RT)-PCR with four internal competitors was combined with electrophoretic separation and quantification of the PCR amplicons on an automated DNA sequencer. From the internal calibration curve, the amount of HIV-1 RNA in the sample could be determined. Furthermore, a primer extension assay was combined with detection and quantification of the competitive PCR products by the same biochemiluminescent detection technique that is used in pyrosequencing. Quantification of HIV-1 viral load has implications in monitoring of antiretroviral therapy and in assessment of disease progression into AIDS.

Key words: bioluminescence, Bordetella, competitive PCR, DNA sequencing, human immunodeficiency virus type 1, PCR, pyrosequencing, solid-phase technology, Vibrio cholerae 
ISBN 91-7170-504-X

\section{LIST OF PUBLICATIONS}

This thesis is based on the following papers, which in the text will be referred to by their Roman numerals:

I. Stark M., E. Reizenstein, M. Uhlén and J. Lundeberg. (1996). Immunomagnetic separation and solid-phase detection of Bordetella pertussis.

J. Clin. Microbiol. 34(4): 778-784.

II. Ronaghi M., M. Nygren, J. Lundeberg and P. Nyrén. (1999). Analysis of secondary structures in DNA by pyrosequencing.

Anal. Biochem. 267(1): 65-71.

III. Nygren M., E. Reizenstein, M. Ronaghi and J. Lundeberg. (2000). Polymorphism in the pertussis toxin promoter region affecting the DNA-based diagnosis of Bordetella infection.

J. Clin. Microbiol. 38(1): In press

IV. Erlandsson A, A. Bäckman, M. Nygren, J. Lundeberg and P. Olcén. (1998). Quantification of Bordetella pertussis in clinical samples by colorimetric detection of competitive PCR products.

APMIS. 106: 1041-1048.

V. Falklind S., M. Stark, M. J. Albert, M. Uhlén, J. Lundeberg and A. Weintraub. (1996). Cloning and sequencing of a region of Vibrio cholerae O139 Bengal and its use in PCR-based detection.

J. Clin. Microbiol. 34(12): 2904-2908.

VI. Vener T., M. Nygren, A. Andersson, M. Uhlén, J. Albert and J. Lundeberg. (1998). Use of multiple competitors for quantification of human immunodeficiency virus type 1 RNA in plasma.

J. Clin. Microbiol. 36(7): 1864-1870.

VII. Nygren M., M. Ronaghi, P. Nyrén, J. Albert and J. Lundeberg. (1999). Quantification using multiple PCR competitors and bioluminescence detection. Manuscritpt 


\section{TABLE OF CONTENTS}

\section{INTRODUCTION}

1. Diagnosis of infectious diseases 1

1.1 Background 1

1.2 Traditional typing methods 2

1.3 Nucleic acid-based typing 3

2. In vitro nucleic acid amplification-based analysis 4

2.1 Sample preparation 10

2.2 Qualitative analysis 12

PCR-based typing $\quad 17$

Specific detection $\quad 18$

Detection of known polymorphisms and mutations 19

$\begin{array}{ll}2.3 \text { Quantitative analysis } & 19\end{array}$

Limiting dilution analysis $\quad 21$

Competitive PCR 23

Kinetic PCR 25

2.4 DNA sequence determination 26

\section{PRESENT INVESTIGATION}

3. Diagnosis of Bordetella infection by PCR (I-IV) 30

3.1 Pertussis and diagnosis of Bordetella infection 30

3.2 Solid-phase sample preparation and detection of Bordetella (I) 32

3.3 Sequencing of a pertussis toxin promoter region used in

DNA-based diagnosis of Bordetella infection (II, III) 34

3.4 Quantification of Bordetella pertussis (IV) 38

4. PCR-based detection of Vibrio cholerae O139 Bengal (V) 40

4.1 Background 40

4.2 Isolation and characterization of a Vibrio cholerae O139 Bengalspecific DNA region $(\mathrm{V})$

4.3 Future analysis of Vibrio cholerae O139 Bengal isolates 43 
5. PCR quantification of human immunodeficiency virus type 1 (VI-VII) 45

5.1 Background

5.2 Quantification of HIV-1 using multiple PCR competitors and gel electrophoresis (VI)

5.3 Quantification of HIV-1 using multiple PCR competitors and bioluminescence detection (VII)

ACKNOWLEDGEMENTS $\mathbf{5 3}$

REFERENCES

ORIGINAL PAPERS (I-VII) 


\section{INTRODUCTION}

\section{Diagnosis of infectious diseases.}

\subsection{Background}

The impact of microorganisms on human health today is essential, in spite of the significant progress in disease control and understanding. In developed countries, infectious diseases such as influenza, pneumonia and tuberculosis were the major cause of deaths in the early 1900s. Now, heart-related diseases, cancer and stroke are the dominating causes of death in developed countries, whereas the risk of dying from an infectious disease in less developed countries is still comparable to the situation in the developed countries one hundred years ago.

The threat from different microorganisms has changed during the human history as we humans have changed lifestyle, demonstrating the intimate relation between microorganisms and their hosts. While some diseases and their causing agents are more or less eradicated, other "new" pathogens are emerging. These pathogens include organisms not isolated or identified before, but also pathogens changing hosts and thereby affecting human health. Increased knowledge has also resulted in inclusion of previously considered non-harmful organisms into the human pathogens (Labenz, 1994). The increased insight into microorganism-host relationship has also revealed an increased risk of developing neoplasia with infection of certain viruses (Brechot, 1997; zur Hausen, 1977) and that infection with one pathogen can result in a predisposition toward other infections (Chang, 1994). Human allelic variation can also be associated with increased susceptibility or resistance towards different pathogens (Hill, 1992; Apple, 1995; Michael, 1999). The recent emergence of multiple drug-resistant forms of bacteria previously easily treated with antibiotics has resulted in a situation resembling the time before antibiotics were available, by some people termed the "post-antibiotic era" (Beardsley, 1992).

Medical microbiology as a science started to develop during the latter part of the 19th century. Essential was Pasteur's work to disprove the theory of "spontaneous generation" and his introduction of sterilization procedures and aseptic techniques 


\section{NYGREN}

(Manchester, 1995). The existence of contagious diseases had been suspected for a long time and Koch confirmed that microorganisms were the cause of infectious diseases by his work on the germ theory of disease (Koch, 1942). According to his well-known postulates, which was an attempt to standardize the proof of causation in infectious disease, the microbe needs to be specifically associated with the disease. The organism should be present in every case of the disease and not in other diseases or in healthy individuals. The microorganism must be repeatedly grown in pure culture outside the body and be able to induce the disease anew when inoculated into susceptible animals.

The pure culture and clonality concepts, where selective media are used together with isolation of single colonies on solid media, were essential for analysis of microorganisms and diagnostics of infectious diseases during almost a century. The introduction of DNA sequencing (Maxam, 1977; Sanger, 1977) and nucleic acid amplification-based methods (Saiki, 1985; Mullis, 1987) during the 1970's and 80's allowed a sequence-based identification of microbes as well as potential findings of new pathogens from a heterogeneous population, without prior cultivation. This substitution of a biological amplification for an enzymatic amplification has been termed the "PCRas-petri-dish metaphor" (Persing, 1993). As a result of this progress, new guidelines for microbe identification and for evidence of disease causation have been suggested (Fredericks, 1996).

\subsection{Traditional typing methods}

The traditional microbiological typing methods rely upon isolation and magnification of the microorganism by culture, after which the organism is identified by examination of the whole organism or by protein- or lipid- based analysis. In biotyping, biograms (Kilian, 1979) are obtained describing the phenotypic characteristics such as morphology (including staining), requirements for growth and metabolism of substrates (i.e. biochemical assays). The differentiating capability needs to be determined for each case and the phenotypic characteristics are not stable but can be affected by for example the technical handling, changes in gene regulation and gain or loss of plasmids. In susceptibility / resistance typing, antibiograms (Blanc, 1994) represent the organism's reaction to anti-microbiological agents, resistograms (Rossney, 1994) show reactions to for example dyes and heavy metals and in bacteriocin typing the organism's reactions to 
toxins are measured. This approach to typing has a low discriminating power and the characteristics measured are easily subject to changes as a result of selective pressure resulting in chromosomal mutations or exchange of plasmids and transposons. Using protein analysis by immunoassays, identification on subtype level is possible ( $\mathrm{Ng}, 1995)$. The analysis can be performed in an agglutination, immunoblot or ELISA format. By electrophoretic methods, typing on strain level is possible (Bannerman, 1995). Wholecell lysates and outer membrane proteins are usually analyzed by denaturating gel electrophoresis (Dijkshoorn, 1996). Active enzymes can be analyzed under nondenaturating conditions in multilocus enzyme electrophoresis (Selander, 1986). Disadvantages with protein-based typing are the difficulty to distinguish between loss and down-regulation of a gene and that mutations not significantly changing the mass or charge of the protein are not detected. In phage analysis, bacteria are subjected to infection by a panel of bacteriophages, resulting in an infection profile, with possible identification at strain level (Pitt, 1995). Using chromatography, cellular fatty acids can be analyzed and the resulting profiles can be used in typing (Asai, 1993).

\subsection{Nucleic acid-based typing}

The first nucleic acid-based methods for identification of microorganisms still required culture to obtain sufficient amount of nucleic acid for the analysis (Tenover, 1995). By using gel electrophoresis, plasmid fingerprints were used to compare different strains of a species and to track anti-microbial resistance (Mayer, 1988). The progress in molecular biology such as the discovery of restriction endonucleases, the possibility to determine the nucleotide sequence of a DNA molecule and to synthesize oligonucleotide probes resulted in the development of several methods useful in diagnostics. Traditional hybridization analysis are still used in certain niche applications such as for direct detection and culture confirmation / typing and for detection by in situ hybridization, but is usually used in combination with other methods. Hybridization-based analysis has had a revival during the last years due to technological developments such as oligonucleotide arrays (Schena, 1998), reporter molecules utilizing FRET (fluorescent resonance energy transfer) (Chen, 1997) and PNA (peptide nucleic acid) (Nielsen, 1991). Hybridization analysis on DNA chips or miniature gel pads (Dubiley, 1997) is suitable for 
miniaturization, parallelisation and automation, and thereby lends it for large-scale DNA analysis.

Even though this thesis primarily deals with diagnosis of infectious diseases and typing of microorganisms, many methods and principles are valid also in the detection of human genetic variations. Those analyses have applications within cancer diagnosis, prenatal diagnosis, diagnosis of some inherited diseases, analysis of gene expression and in determination of an individual's susceptibility to certain infectious agents and potentially also to hazardous environmental agents (Wagener, 1997), but this will not be discussed any further in this work.

\section{In vitro nucleic acid amplification-based analysis}

One of the benefits with the current large-scale genome sequencing projects is the rapidly increasing amount of sequence data accessible in the public databases. The largescale sequencing projects have also contributed with improvements both on the computerized analysis of sequence data and by accelerating the nucleic acid sequencing technology. This has resulted in sequencing protocols which are simple to perform with enzymes and reagents available as prefabricated kits and more or less automated instruments for DNA sequencing, making DNA sequencing and reporting of sequence data possible for an increasing number of laboratories.

In the different nucleic acid amplification technologies, the available sequence information is used to design probes in order to detect a specific nucleic acid sequence by a probe hybridization event and some kind of amplification event. The amplification process itself constitutes only one part of the complete analysis (Fig. 1). A sample preparation step is usually necessary, adapted to the sample specimen and to the amplification method of choice. The type of amplification method is determined by the nucleic acid sequence to be analyzed, but primarily by the demands defined by the downstream analysis required for a specific application (see below). 


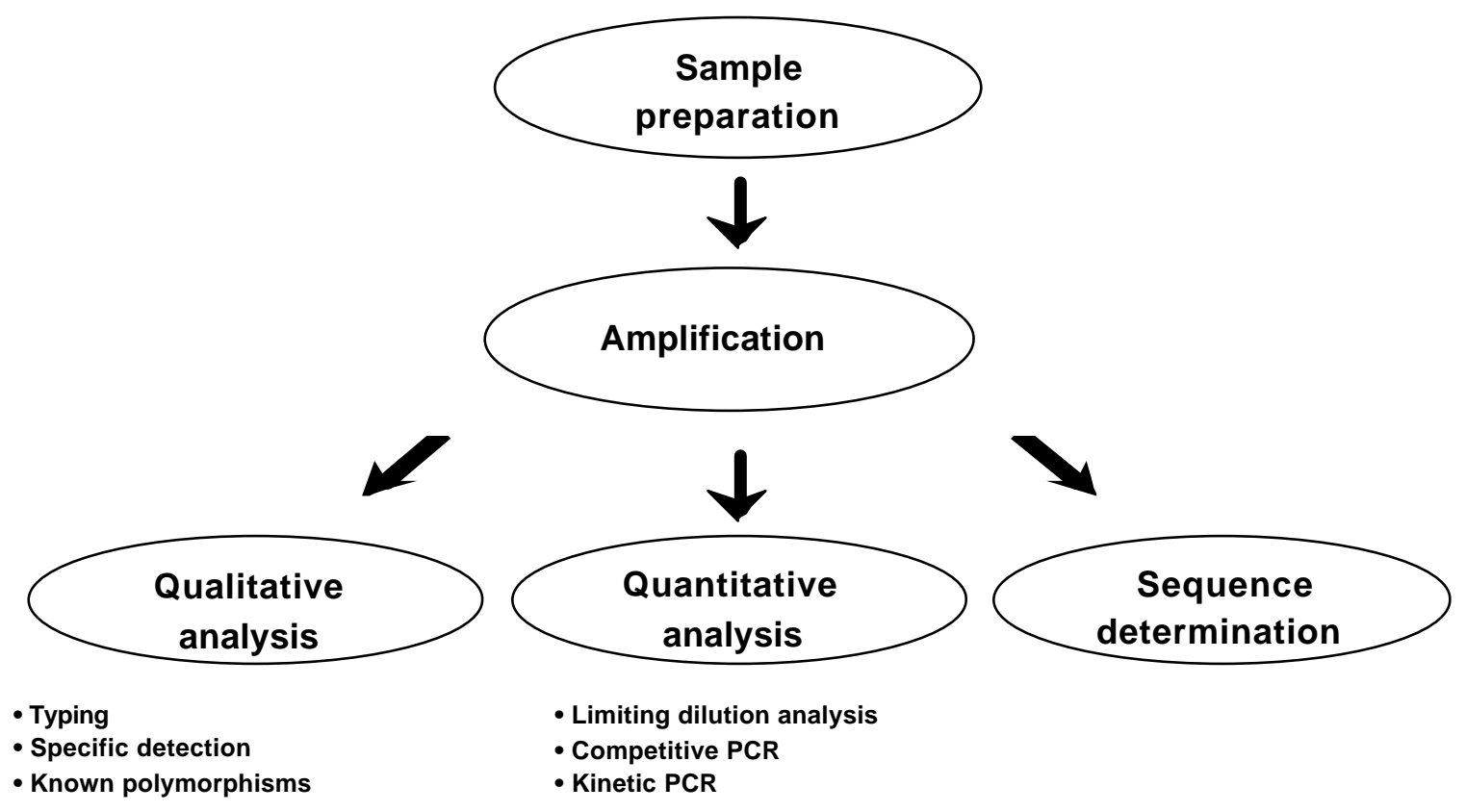

Figure 1. Nucleic acid amplification-based analysis.

Based on the amplification mechanism, the amplification methods can be divided into three groups; (i) target amplification methods, (ii) probe amplification methods and (iii) methods based on signal amplification (Table 1). To be classified as a target amplification technique, target-specific sequence information must be a part of the resulting amplification product. Target amplification methods are suitable for amplification with broad range primers followed by further characterization of the amplified target sequence replica. The predominant target amplification method is the polymerase chain reaction (PCR) (Mullis, 1987; Saiki, 1985) (Fig. 2A), but selfsustaining sequence replication / nucleic acid sequenced-based technology (3SR/NASBA) (Compton, 1991; Guatelli, 1990) have a potential advantage over PCR in applications where selective amplification of RNA is advantageous. In the probe amplification methods (exemplified by the ligase chain reaction (LCR) (Barany, 1991) in Fig. 2B), no sequence information beyond what is present in the probe itself is included in the product. This fact restricts the applications of these methods to cases where detection of the presence of a signature nucleotide sequence in the sample is sufficient. 


\section{NYGREN}

Target-directed ligation methods are useful for the detection of point mutations, by designing the oligonucleotides to have their point of ligation located at the nucleotide position of a known point mutation. In signal amplification techniques (represented by branched DNA (bDNA) technology (Urdea, 1991; Sanchez-Pescador, 1988) in Fig. 2C), detectable signals are achieved by a series of hybridization events to increase the number of labels per target molecule. The bDNA approach is possible to use also on targets with sequence heterogeneity due to the discontinous design of multiple probes. As bDNA probes provide a broad quantitative detection range, this method is suitable also for quantitative assays. The signal amplification methods that do not generate amplifiable products are thus less susceptible for product contamination.

Figure 2. Examples of nucleic acid amplification techniques, represented by a target-, a probe-and a signal amplification method. In the polymerase chain reaction (PCR) (A), the internal product sequence between the by PCR incorporated primer sequences is identical to the target sequence, except from potential errors introduced by the DNA polymerase. The amplification specificity is a result of the requirement for the two primers to hybridize at opposite strands, relatively close to each other and of the DNA polymerase preferring matched 3' ends to initiate DNA synthesis. The amplification product obtained in the ligase chain reaction (LCR) (B) contains only DNA sequence originally present in the probes themselves. A complementary base at the $3^{\prime}$ end of the probe result in much more effective ligation of probes than do mismathed bases, contributing to the specificity of amplification. In branched DNA (bDNA) amplification (C), neither target nor probe sequence is amplified. Several independant probe hybridization events are required to give a strong signal. 


\section{MOLECULAR DIAGNOSTICS OF INFECTIOUS DISEASES}
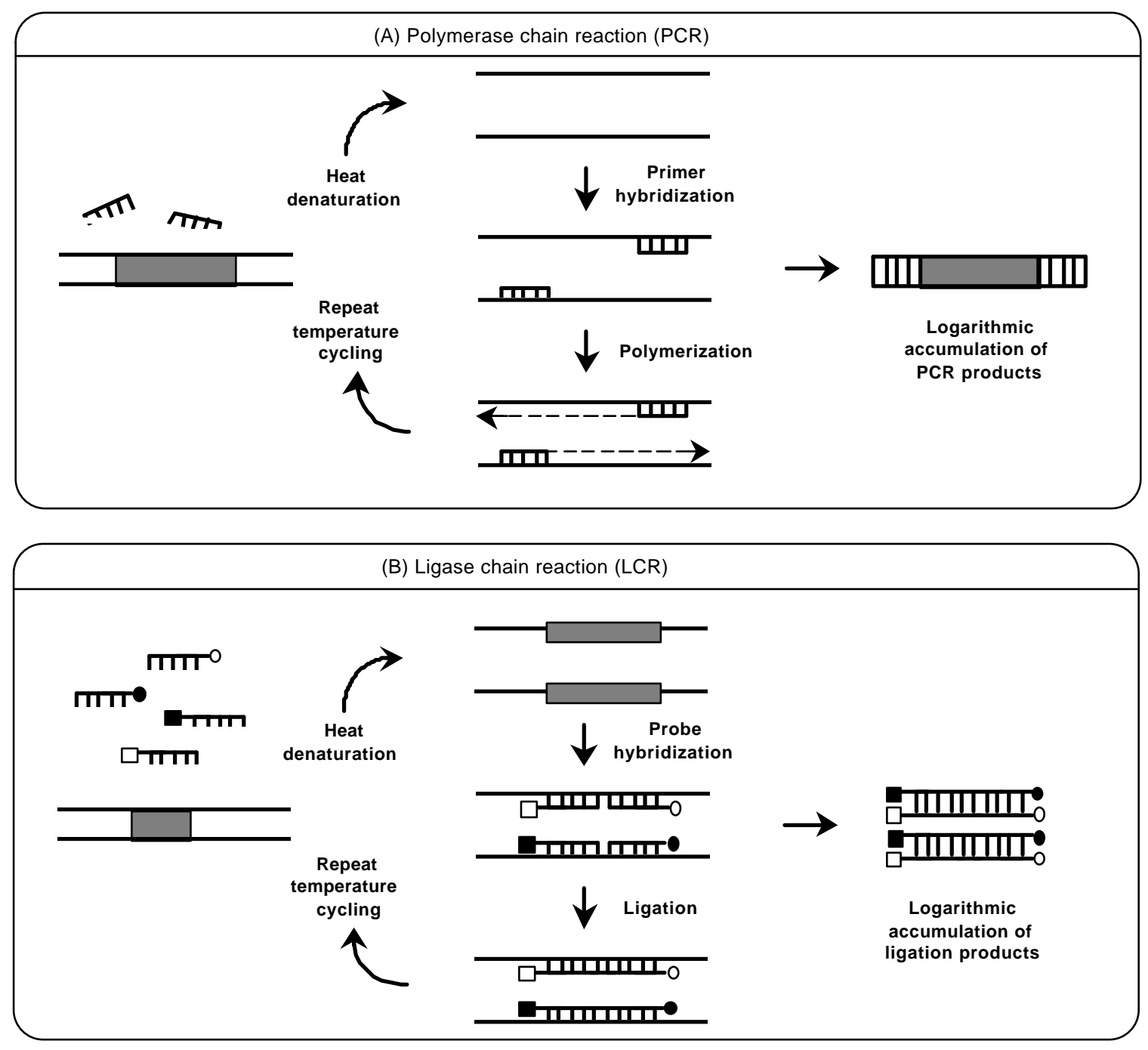

(C) Branched DNA (bDNA)-based detection

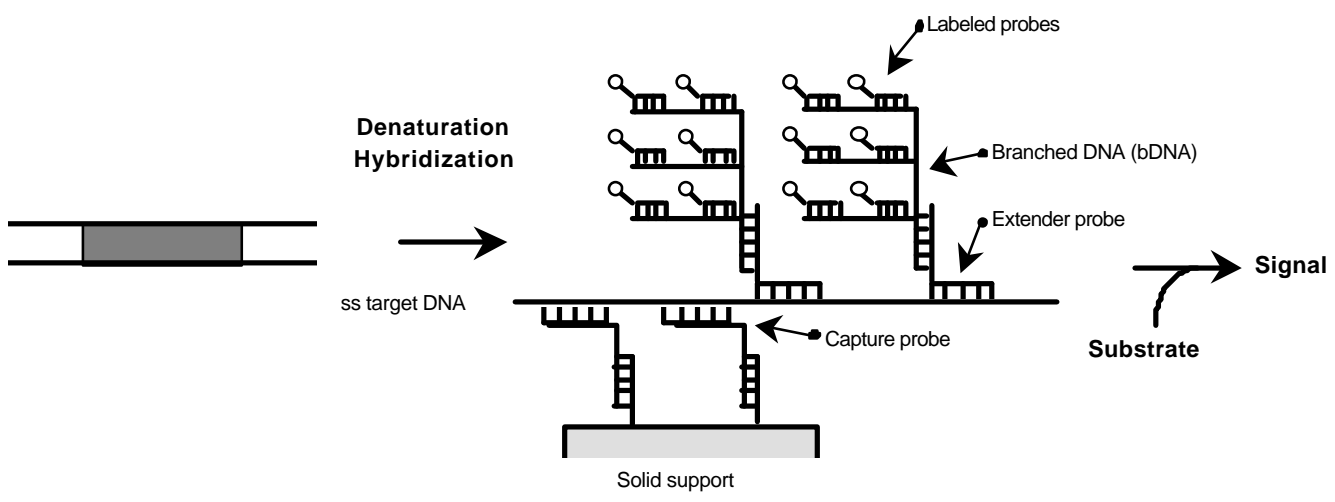


Table 1 Examples of nucleic acid amplification methods.

\begin{tabular}{|c|c|c|c|}
\hline $\begin{array}{c}\text { Amplification } \\
\text { method* }\end{array}$ & References & Probe molecule & Enzymes used \\
\hline \multicolumn{4}{|l|}{ Target } \\
\hline PCR & (Saiki, 1985), (Mullis, 1987) & two primers & thermophilic DNA polymerase \\
\hline TAS & $($ Kwoh, 1989) & $\begin{array}{l}\text { primers (one with T7 RNA polymerase } \\
\text { promoter) }\end{array}$ & reverse transcriptase, RNA polymerase \\
\hline 3SR/NASBA & $\begin{array}{l}\text { (Guatelli, 1990), (Compton, } \\
\text { 1991) }\end{array}$ & $\begin{array}{l}\text { primers (one with } \mathrm{T} 7 \mathrm{RNA} \text { polymerase } \\
\text { promoter) }\end{array}$ & $\begin{array}{l}\text { reverse transcriptase, (RNAse H), RNA } \\
\text { polymerase }\end{array}$ \\
\hline SDA & (Walker, 1992) & $\begin{array}{l}\text { primers with restriction endonuclease } \\
\text { recognition sequence }\end{array}$ & $\begin{array}{l}\text { restriction endonuclease, DNA } \\
\text { polymerase }\end{array}$ \\
\hline \multicolumn{4}{|l|}{ Probe } \\
\hline LAR & $(W u, 1989)$ & probes hybridized head-to-tail & DNA ligase \\
\hline LCR & (Barany, 1991) & probes hybridized head-to-tail & thermophilic DNA ligase \\
\hline $\begin{array}{l}\text { QB replicase- } \\
\text { based } \\
\text { amplification }\end{array}$ & (Kramer, 1989),(Lomeli, 1989) & $\begin{array}{l}\text { Folded substrate probe with target-specific } \\
\text { region and RNAse III sensitive site }\end{array}$ & QB replicase \\
\hline RCA & (Fire, 1995), (Lizardi, 1998) & padlock probe and two additional probes & DNA ligase, DNA polymerase \\
\hline \multicolumn{4}{|l|}{ Signal } \\
\hline Compound probes & (Klausner, 1988), (Yang, 1991) & primary probe and labeled secondary probes & none \\
\hline bDNA probes & $\begin{array}{l}\text { (Urdea, 1991), (Sanchez- } \\
\text { Pescador, 1988) }\end{array}$ & $\begin{array}{l}\text { capture probes, extender probes, branched } \\
\text { amplification multimers and labeled probes }\end{array}$ & none \\
\hline Invader & (Lyamichev, 1999), (Ryan, 1999) & $\begin{array}{l}\text { two overlapping oligos and a secondary signal } \\
\text { probe }\end{array}$ & flap endonuclease \\
\hline
\end{tabular}

*PCR-polymerase chain reaction, TAS-transcription-based amplification system, 3SR-self-sustaining sequence replication, NASBA-nucleic acid sequence-based amplification, SDA-strand displacement amplification, LAR-ligase amplification reaction, LCR-ligase chain reaction, RCA-rolling circle amplification, bDNA-branched DNA. 
Today, due to its in-built versatility and flexibility, PCR is the most widely used and best developed amplification method with the most diverse applications. Since the invention of the PCR, numerous improvements and modifications on the amplification process itself have been presented. Together which with the discovery and engineering of polymerases with more optimal performance (thermostability, reverse transcription activity, incorporation of dideoxynucleotides, improved processivity and proofreading) these have made possible for example hot start (Mullis, 1991; Chou, 1992; Kellogg, 1994; Birch, 1996; Nilsson J, 1997), other primer-dimer reduction methods (Brownie, 1997), RT-PCR (Young, 1993; Myers TW, 1991), long PCR (Barnes, 1994), high fidelity PCR (Lundberg, 1991), in situ PCR (Nuovo, 1993) and cycle sequencing (Carothers, 1989; Innis, 1988) (see below). A deeper understanding of the factors affecting the amplification mechanism and of the importance of PCR optimization and standardization and proper internal PCR controls as well as the availability of different contamination control approaches have, in spite of the early doubts, allowed implementation of PCR also in clinical use. Improved amplification characteristics have together with the developments on PCR product detection methods allowed for quantitative PCR analysis (see below) and multiplex amplification (Chamberlain, 1988; Wang, 1998). By using the Bridge technology based on acrydite attached amplification primers, extreme multiplexing can be achieved and thereby facilitating PCR generation of hybridization targets for DNA array analysis (Mitra, 1999).

The instrumentation to perform PCR has also undergone extensive development since the first generation PCR instruments. For example, extremely rapid temperature cycling does not only shorten the amplification time but also greatly improves the amplification process itself by reducing nonspecific reactions and thereby increasing the sensitivity, specificity and product yield. Rapid temperature cycling can be performed in commercially available instruments using air-heated micro-capillaries (Wittwer, 1990) or in microfabricated silicon-based reaction chambers (Cheng, 1996; Burns, 1996; Northrup, 1998). The PCR chip approach also permits integration of PCR amplification and product analysis by capillary electrophoresis on the same microchip (Woolley, 1996). Both the micro-capillary system and a silicon chamber microchip have now also successfully been combined with kinetic (real-time) detection of the PCR product formed (Wittwer, 1997; Northrup, 1998). The development of a portable, battery-operated, 
miniature chip-based instrument using rapid thermocycling and real-time detection has allowed for example analysis of single-base polymorphism in less than one hour, including the time required for sample preparation (Ibrahim, 1998). A completely different chip approach to reduce sample and reagent volume and increase throughput is the recently reported continuous-flow PCR, where the samples are injected serially into a single buffer-containing channel, repeatedly passing over three different temperature zones where DNA denaturation, primer hybridization and extension occur (Kopp, 1998).

\subsection{Sample preparation}

When culture is replaced by PCR for the detection and analysis of a microorganism, a signature sequence is chosen as a representation of the entire genome of the organism and in some cases also of its evolutionary history. Genotypic analysis has multiple advantages compared to the study of phenotypic characteristics, such as rapidness, sensitivity, specificity and by producing readily quantified and standardized data. However, additional questions may arise, such as the consequence of the ability to detect also nonviable bacteria i.e. residual nucleic acid after initiation of effective therapy. This might be advantageous in diagnosis of microorganisms sensitive to transport and storage. Some species contain a high micro-heterogeneity and when comparing nucleic acid sequences less than a $100 \%$ identity might need to be defined as matching. Furthermore, in some cases the genetic variation may have no phenotypic or clinical correlate. When using highly conserved primers, the over-sensitivity of PCR can detect environmental contamination, irrelevant opportunists or natural, co-existing flora. Sometimes it is not possible to find microbial nucleic acid in the diseased tissue due to pathogens with widespread systemic effects caused by exotoxins. Thus, when choosing nucleic acid target region for amplification, several aspects need to be considered. Examples also include whether DNA or RNA should be amplified, if an open reading frame or a non coding region should be chosen, a conserved or divergent sequence and the implications of choosing a single or multiple-copy target gene.

An absolute requirement for a successful nucleic acid amplification analysis is a high quality template and careful precautions to prevent contamination. The main goals of the sample preparation is to release and stabilize the nucleic acid, to concentrate the target, remove inhibitors and obtain the nucleic acid in a protective buffer, compatible 
with the enzymatic amplification. The choice of sample preparation method is also dependent on the properties of the isolated organism and the physical properties of the specimen. An optimal sample preparation method is also convenient, robust, safe and possible to automate. With the introduction of rapid-cycling PCR instruments and realtime detection techniques, the sample preparation step is often the rate-limiting step of the analysis and also the most difficult part to miniaturize.

A large number of specimen types, such as blood, plasma, serum, cell fractions, cerebrospinal fluid, sputum, urine, faeces, nasal washes, swabs, formalin fixed paraffinembedded tissue and also food and environmental samples, are potential sources of nucleic acids possible to amplify after suitable treatment (Greensfield, 1993). DNA polymerase inhibitors are often present in crude samples, but can also be introduced into the sample during the sample preparation procedure. Nucleic acids can be released from samples by several techniques such as boiling, freeze-thawing, sonication, or by treatment with sodium hydroxide, detergents, chaotropes and proteases (Greensfield, 1993). The nucleic acid is then extracted, precipitated and / or captured to a matrix. Commercial kits exist for isolation of DNA or RNA from a wide variety of specimen types. These are usually based on enzymatic lysis, binding of the nucleic acid to matrixcontaining spin columns using spin or vacuum technology for washing and buffer exchange. Alternatively, magnetic particles with coupled nucleic acid probes can be used for nucleic acid capture, utilizing a magnetic device for collection of the beads when buffer is changed (Albert, 1992; Deggerdal, 1997; O'Meara, 1998). A potential shortcut in sample preparation is to capture the whole target organism by for example immunomagnetic separation (Olsvik, 1994) or filtration (Bej, 1991), wash the isolated target and add it directly to the PCR vial, where it is lyzed prior to amplification. 


\section{NYGREN}

\subsection{Qualitative analysis}

To be able to choose the most suitable method to analyze the result after nucleic acid amplification, several aspects need to be considered, including for example the level of specificity in the amplification. A highly specific PCR amplification may not need sequence confirmation by a probe hybridization detection method. On the other hand, when the amplification product is expected to be heterogeneous and perhaps rare sequence variants need to be detected, which can occur for example in HIV analysis and in the search for new pathogens, low-stringent hybridization is required if a hybridization method is to be used. In some cases a method which separates the amplification product according to molecular size is advantageous.

PCR product detection methods can be divided into two groups (Table 2), heterogeneous and homogeneous methods. The heterogeneous methods all require postPCR manipulations such as aliquoting the product, loading of samples onto a gel or a column; transfer of product onto a membrane, chip or other solid phase; addition of proteins or nucleic acid probes and substrates; or enzymatic ligation or nucleotide extension reactions. Attempts have been made to fully automate these manipulations (Brown, 1999). Three fundamentally different heterogeneous detection methods are exemplified in Figure 3; hybridization-based analysis (using a DNA chip, Fig. 3A), enzymatic extension analysis (using minisequencing, Fig. 3B) and mass analysis (using mass spectrometry, Fig. 3C).

Figure 3. Examples of heterogeneous PCR product detection methods. Hybridization on DNA chips (A) can be performed in both a dot blot and a reverse dot blot fashion. Hybridization is detected by radiolabeling or more often fluorescence, which permits the detection of multiple dyes simultaneously. Minisequencing (B) can now also be performed in one tube by using differently labeled ddNTPs. DNA analysis by mass spectrometry (C) is usually performed by using matrix-assisted laser desorption / ionization time of flight (MALDI-TOF) MS. If single nucleotide polymorphisms are to be distinguished, only short oligonucleotides can be analyzed. 
(A) DNA chips
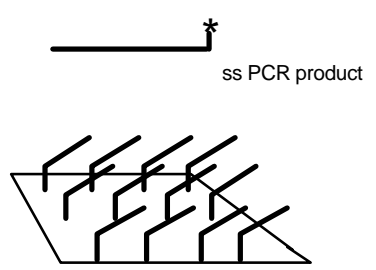

Hybridization Detection

High-density oligonucleotide array

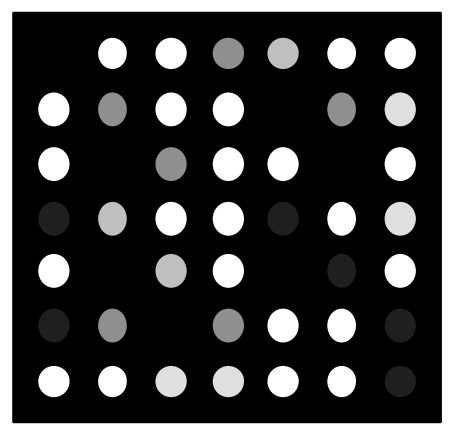

Image showing different hybridization intensities

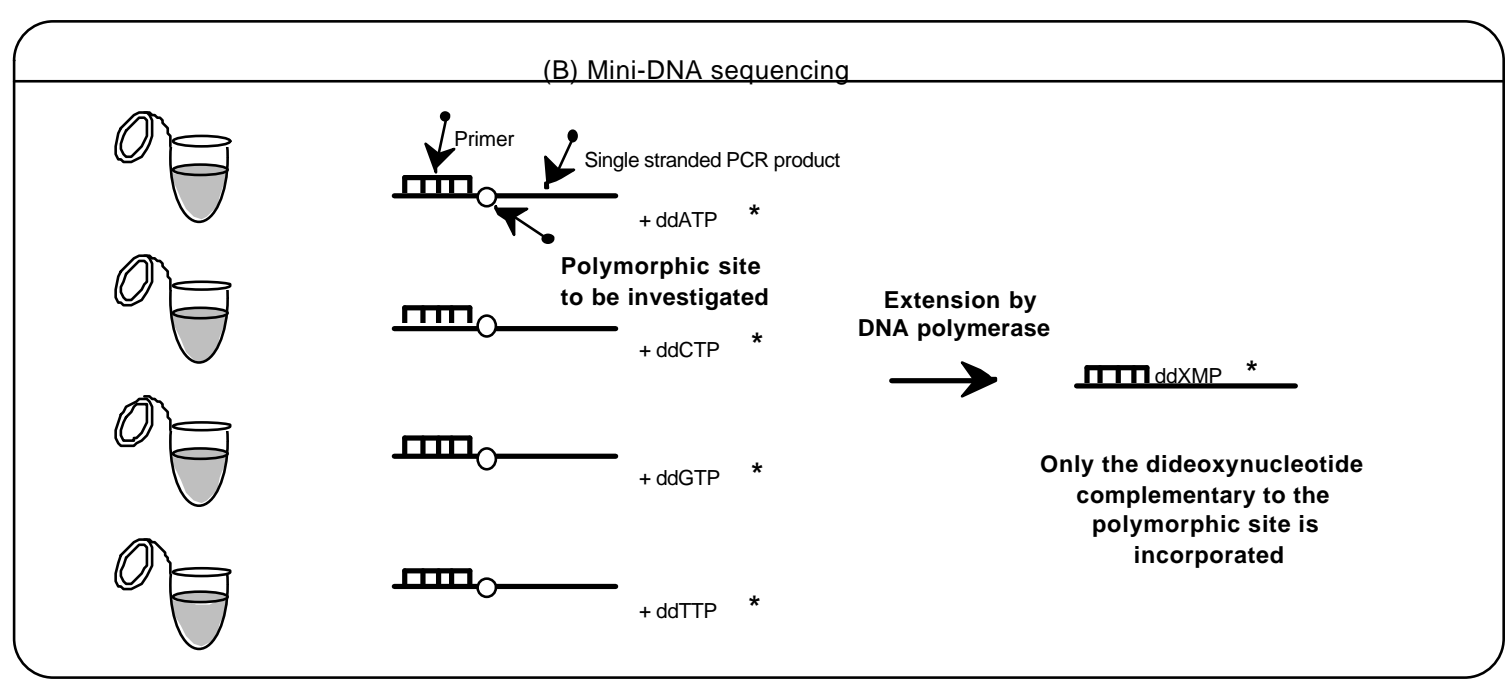

(C) Mass spectrometry detection

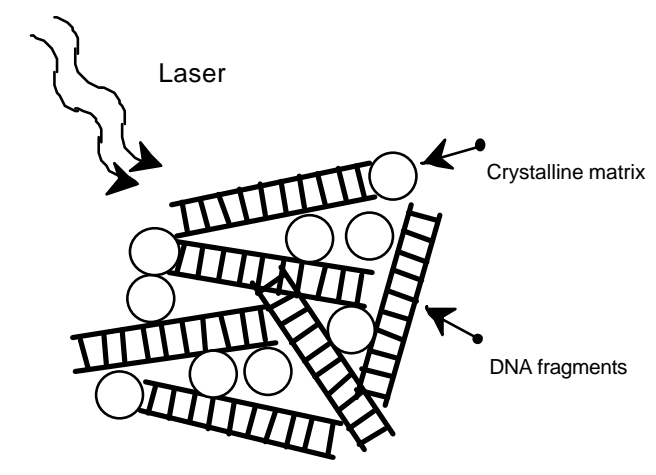

(1) Desorption \& ionization

(2) Acceleration in electric field

(3) Detection

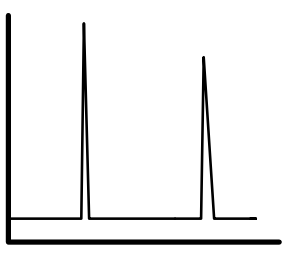

$\mathrm{m} / \mathrm{z}$ 
Table 2. Examples of PCR product detection and analysis methods

\begin{tabular}{ll}
\hline \hline Detection methods & References
\end{tabular}

\section{Heterogeneous}

Gel electrophoresis

Capillary electrophoresis (CE)

High performance liquid chromatography (HPLC)

Dot blot

Reverse dot blot

DNA enzyme immunoassay (DEIA)

Electrochemiluminescence

High density DNA array

Surface plasmon resonance

DNA-binding proteins

Oligonucleotide ligation assay (OLA)

Primer extension assay

Mass spectrometry (MS)

Pyrophosphate ion complexes
(Mullis, 1987)

(Schwartz, 1991), (Fasco, 1995)

(Oefner, 1994)

(Bugawan, 1988)

(Saiki, 1989)

(Mantero, 1991)

(DiCesare, 1993)

(Schena, 1995)

(Nilsson P, 1997), (Kai, 1999)

(Kemp, 1989), (Wahlberg, 1990)

(Landegren, 1988)

(Shumaker, 1996), (Syvänen, 1990)

(Hillenkamp, 1991)

(Gibson a, 1997)

\section{Homogeneous}

Hybridization protection assay (HPA)

(Arnold, 1989), (Nelson, 1996)

Fluorescence polarization

(Gibson b, 1997)

PCR with intercalating dye

(Higuchi, 1992)

5 ' exonuclease assay (TaqMan)

(Holland, 1991), (Livak, 1995)

Sunrise primers (Amplifluor)

(Nazarenko, 1997), (Uehara, 1999)

Molecular beacons

(Tyagi, 1996)

Scorpion primers

(Whitcombe, 1999)

Adjacent fluorescence hybridization probes

(Wittwer, 1997)

Dye-labeled oligonucleotide ligation (DOL)

(Chen, 1998)

Product-product annealing kinetics

(Ririe, 1997) 
A homogeneous method detects the amplification product inside the closed PCR tube and often in real-time, without addition of any further reagent components, which also reduces the risk for carry-over contamination. The homogeneous methods can be further divided into unspecific methods, which detect the correct amplicon as well as primer-dimer and other unspecific products (e. g. using intercalating dyes, Fig. 4A), and specific methods, which only detect amplification products containing internal, targetspecific sequence (e. g. using TaqMan probes and Scorpion primers, Fig. 4B and C).

Heterogeneous methods have a potential advantage when multiple analyses are to be performed on the same PCR sample. However, the availability of multiple dyes (FRET-pairs) has now allowed kinetic detection of multiple targets or sequence variants simultaneously in the same tube (Tyagi, 1998; Kostrikis, 1998). Despite the wide range of detection methods available, several detection principles need often to be combined to achieve optimal analysis of for example polymorphic positions in genotyping, in gene expression analysis and in other quantitative applications. Minisequencing reactions can for example be performed on an oligonucleotide array (Pastinen, 1997). Oligonucleotide single-base extensions (Higgins, 1997) or extension products obtained with a mixture of deoxyribonucleotide triphosphates and dideoxyribonucleotide triphosphates (Braun, 1997) can be analyzed by matrix-assisted laser desorption / ionization (MALDI). The methods used for detection and analysis of PCR products are of course used also in combination with non-PCR amplification techniques. For example, the Invader technology uses quenched fluorescent probes (Lyamichev, 1999) and transcription mediated amplification (TMA) products can be combined with a hybridization protection assay (HPA) for detection of viral RNA (Nelson, 1998). Recently, a number of hyper sensitive, nucleic acid-based principles for detection without amplification have been proposed. These methods make use of physical phenomena such as surface-enhanced resonance Raman scattering (Graham, 1997), fluorescence correlation spectroscopy (Eigen, 1994), electrophoretic velocity (Castro, 1995) or color change upon aggregation of gold nanopatricles coupled to hybridization probes (Elghanian, 1997). It remains to be proved if these approaches are sensitive enough and may have the potential to overcome the problems with high background, when complex samples such as the human genome are analyzed. 


\section{NYGREN}

(A) Intercalating dye

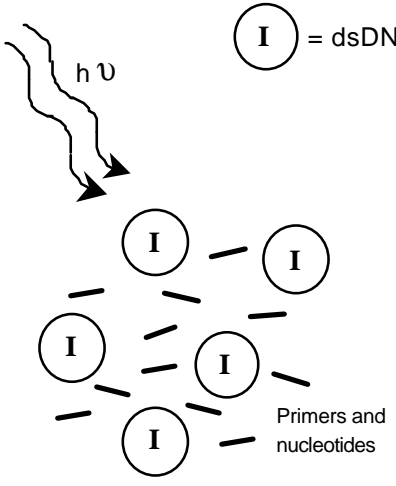

Amplification

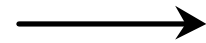

Increased fluorescence

(B) TaqMan assay

DNA polymerase 5'exonuclease hydrolysis of dual-labeled probes

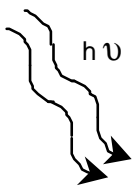

Lonor $\int_{\text {(proximity }}^{\text {Acceptor }}$

(proximity dependent quencher)

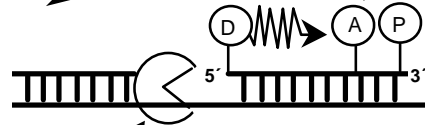

1

DNA polymerase

(5'exonuclease activity)

\section{Amplification}
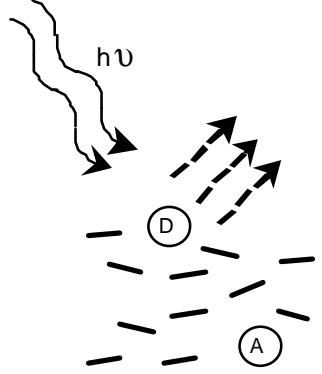

Increased donor fluorescence

(C) Scorpion primer assay

Self-probing of primer extension product
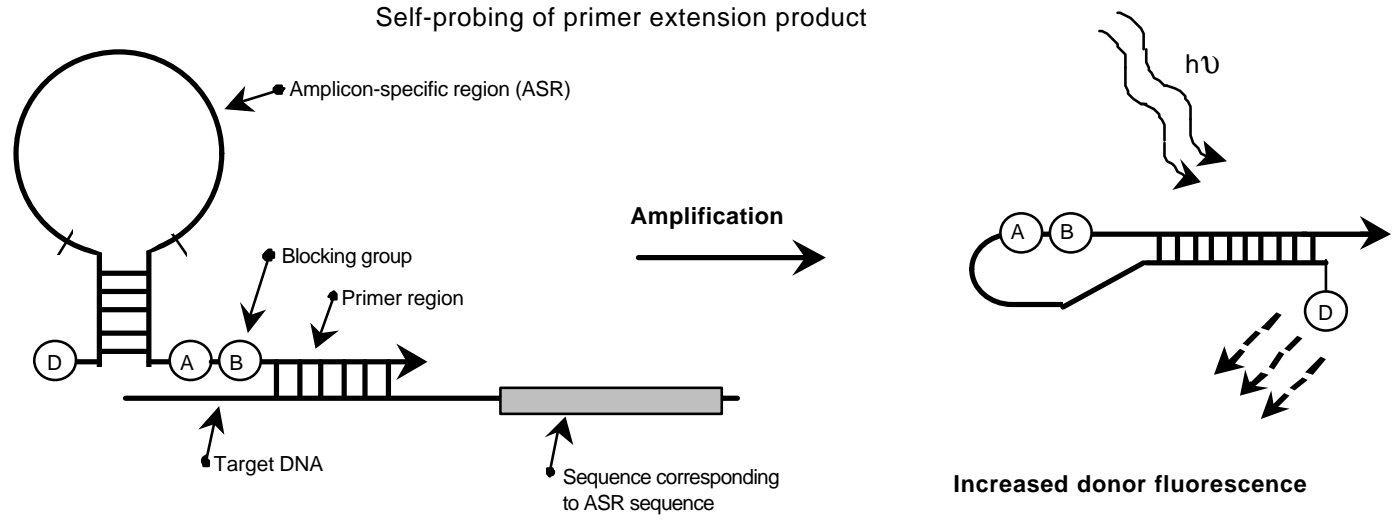

Increased donor fluorescence 
Figure 4. Examples of homogeneous PCR product detection methods. PCR can be performed in the presence of an intercalating dye (I) (A), such as ethidium bromide or SYBR Green I. The linear detection range is limited by the detection of non-specific products after many cycles and by the amount of dye becoming limiting at high product concentrations. The specificity of this method is strongly dependent on the specificity of the PCR primers. In 5' exonuclease assays (B), the highly distant-dependent energy transfer between the donor (D) and acceptor (A) stops as the probe is hydrolyzed. The detection probe is protected from extension by a 3' phosphate $(\mathrm{P})$. The probe needs to be carefully designed for both efficient hybridization and cleavage. The higher specificity obtained with sequence-specific probes is useful in the detection and quantification of low-copy-number samples. The Scorpion primer (C) combines the PCR primer and detection probe functions, resulting in a concentration-independent, unimolecular hybridization event. The hybridization of the amplicon-specific region to the recently synthesized target sequence separates the donor (D) and acceptor (A). No hydrolysis is required, but the primer needs to be carefully designed to have optimal hybridization characteristics. The stem of the hairpin probe contributes also to higher specificity of the assay. The blocker (B) protects the hairpin structure from being copied during the PCR extension step.

Below, three different (I-III) variants of qualitative determinations and some common applications in nucleic acid amplification-based detection and analysis of microorganisms will be discussed briefly.

\section{(I) PCR-based typing}

PCR (or another target amplification method) can be combined with other techniques to allow typing of microorganisms on different levels of specificity, also at intra-species level. PCR can for example be used to amplify a known sequence, which subsequently is cleaved into a characteristic fragment pattern by use of restriction endonucleases. The result of PCR-RFLP (restriction fragment length polymorphism) is usually visualized by using gel electrophoresis (Sayada, 1991). An advantage to previous used methods is that no Southern blotting or probing is necessary. Another approach is to use RAPD (random amplification of polymorphic DNA, also called arbitrary PCR), a low stringent amplification with short, arbitrary primers to generate simple and reproducible 
fingerprints of genomic DNA (Williams, 1990; Welsh, 1990). This is a cost-effective analysis that eliminates the restriction step and does not require any prior sequence information. Broad-range PCR can be used for microbial identification at different levels of specificity depending on the choice of genomic region to be amplified by PCR. Preferred regions are those containing both relatively conserved regions allowing design of universal primers and hypervariable regions for identification. When the sequences of relevant organisms are known, hybridization of the PCR product to specific probes on a chip can be used to achieve a differential diagnosis when the clinical question is restricted to a group of organisms (Kaufhold, 1994). Molecular strain typing is also useful in molecular epidemiology to compare clinical and environmental isolates, to identify single-source outbreaks, to distinguish between relapse and re-infection, to study the structure and the gene flow within a pathogen population.

\section{(II) Specific detection}

This kind of "yes / no" diagnostics relies on the PCR amplification (or any other nucleic acid amplification method) with primers of proven target organism specificity. Virtually any PCR product detection method (Table 2) can be applied, since only the presence or absence of product needs to be proved. Rapid, specific, PCR-based tests are useful in the diagnostic identification of known but uncultured (Relman, 1993), fastidious (Buck, 1996), slow-growing (Ichiyama, 1996) or hazardous (Gruner, 1994) organisms, especially where alternative diagnostic methods such as serological determination are too slow or not sensitive enough. Other applications are in epidemiological investigations, especially in outbreak situations (Keene, 1997), and in retrospective studies of archival clinical specimen (Salo, 1994). The requirement from the authorities to detect viral contaminants in plasma pools used for different blood products by validated nucleic acid amplification-based technology has increased. A large number of amplification-based qualitative tests for a wide range of organisms are now commercially available. By amplification of genes encoding virulence factors causing a certain disease, potentially toxin-producing infectious agents can be identified (Johnson, 1991). A disadvantage compared to patient diagnostics by culture-based isolation and analysis is that an antibiotic resistance assessment need to be done separately by traditional methods or by a 
nucleic acid amplification assay (see below), if the susceptibility profile of the organism is not known.

\section{(III) Detection of known polymorphisms and mutations}

Another example of qualitative, nucleic acid amplification-based analysis is the detection of known nucleotide mutations or polymorphisms in a target sequence. PCR can be combined with several detection principles (Table 2) to achieve single base change detection. Sequence-specific PCR amplification is a sensitive method for singlebase discrimination (Wu, 1989; Newton, 1989). In the hybridization-based detection methods, differences in hybridization characteristics between a perfect match and single nucleotide mismatch are used to detect mutations. Other methods rely on sequencespecific ligation of oligonucleotides or specific extension of perfectly matched primers. In research, a large number of polymorphic positions are often studied in relatively few samples, whereas in clinical applications, a larger number of samples are usually investigated for fewer variations. Applications in microbiology include differentiation between closely related strains (Ibrahim, 1997), study of human allelic variations affecting the susceptibility or resistance to infectious agents (Hill, 1992; Apple, 1995; Michael, 1999), detection of antibiotic resistance in bacteria (Tenover, 1994) and viral drug resistance (Larder, 1989; el-Farrash, 1994) in cases where the genetic basis is known and relatively simple. When the genetic mechanism involved in resistance is unknown or complex, quantification of viral load (Mellors, 1996) is an alternative approach for indirect determination of drug resistance (see below).

\subsection{Quantitative analysis}

As a result of the successful developments in both amplification-based technology and in amplification product detection methods, a large number of approaches to quantitate nucleic acids have been reported during the last decade. The considerable improvements in sensitivity as well as accuracy compared with conventional hybridization-based methods such as Southern and Northern blots, dot-blot, nuclease protection assays and in situ hybridization have also expanded the application area of quantitative nucleic acid analysis. Amplification-based quantitation is today used in a wide range of fields, such as in quantitation of bacteria, parasites and viruses, primarily to 
monitor the effect of anti retroviral therapy. Quantitation by RT-PCR has also potential in analysis of gene expression, especially in the cases of low-abundant mRNAs (Loitsch, 1999) or RNA from few or single cells (Fiorenza, 1998). Other application areas are quantitation of transcripts to monitor gene therapy (Wolff, 1992) or estimation of drug resistance gene products (el-Osta, 1999) and quantitation of host cell DNA contamination in pharmaceutical-grade plasmid preparations (Lahijani, 1998; Smith, 1999).

The choice of quantitation assay depends primarily on the demands on sensitivity and accuracy and the quantification range needed in a specific application but also whether an absolute quantitation is necessary or if a relative quantitation is sufficient or even more suitable. In clinical practice, commercial kits containing reagents for sample preparation and amplification, primers and quantitation standards are now widely used for quantitation of HIV-1 RNA in plasma. The kits on the market are based on different amplification technologies. The AMPLICOR HIV-1 Monitor test (Roche) is based on PCR, NASBA HIV-1 QT (Organon Teknika) uses nucleic acid sequence-based amplification and enhanced sensitivity-bDNA (Chiron) utilizes signal amplification by branched DNA probes. Although these three tests rely upon fundamentally different amplification technologies and also use different protocols for sample preparation, contain different types of control nucleic acids and detect the amplification products by different methods, they seem to show comparable performance characteristics. When compared to each other, inter-laboratory variation with the same kit seems to be greater than the variations between the three kits (Lin, 1998).

For research purposes, PCR-based assays dominate. A large number of strategies have been developed to circumvent the inherent exponential, non-quantitative nature of PCR and the number of published reports on applications of PCR-based quantitation have increased dramatically during the last years. In fact, every approach demonstrating both a calibration curve defining the range within quantification is possible and sufficient replicate samples to perform statistic evaluation of variability is adequate for that specific application (Halford, 1999).

Below, three entirely different (I-III) approaches to quantitative PCR will be described briefly. 


\section{(I) Limiting dilution analysis}

PCR has successfully been combined with limiting dilution and Poisson statistics to determine the number of nucleic acid targets in an unknown sample (Brinchmann, 1991; Sykes, 1992). This approach to quantitation is attractive by avoiding many of the problems and assumptions associated with the most frequently used methods (see below). The basic principle of limiting dilution analysis is quantitation of the number of initial nucleic acid targets present in a sample, without quantitation of the actual amount of PCR product formed. The sample is terminally diluted to an all-or-none end point (Fig. 5A). To secure that as little as one target gives rise to a positive end point, a nested amplification is usually required. To achieve quantitation, multiple replicates at serial dilutions are assayed and the number of targets are calculated by applying Poisson statistics on the fractions of positive and negative samples at the limit of dilution, where only some of the parallel PCR reactions result in a product. The PCR products can be detected by any detection method, since only a qualitative determination is required. The drawbacks of this method involve handling of a large number of PCR tubes per unknown sample and the contamination aspect of nested amplification. These disadvantages may be overcome by combining nanoliter scale PCR with TaqMan detection, thereby achieving saturated amounts of PCR products from a single DNA copy in one round of PCR (Kalinina, 1997). 


\section{NYGREN}

(A) Limiting dilution analysis

(1) First target dilution series

(2) Second target dilution series

IIIIIIII

Multiple replicates of dilutions

around the end-point from step \#1

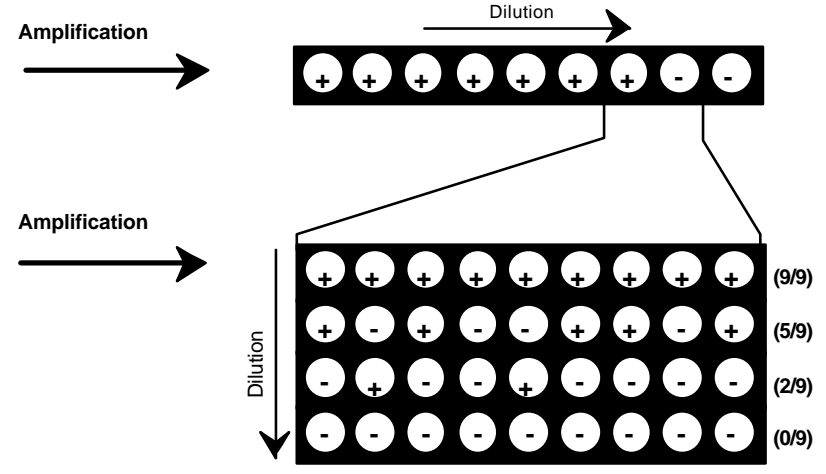

(B) Competitive amplification

Target (fixed amount)

IIIIIIII

$+$

Competitor (dilution series)

IIIIIII
Co-amplification

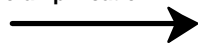

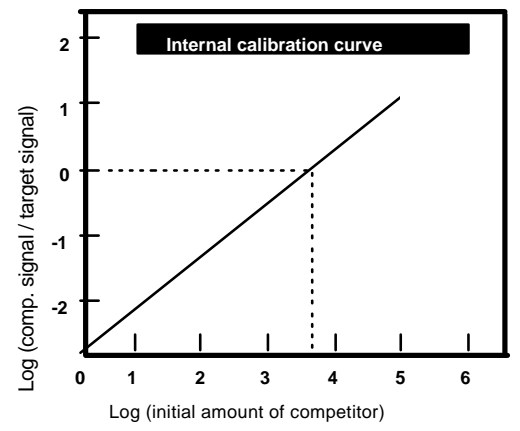

(C) Kinetic amplification

(1)

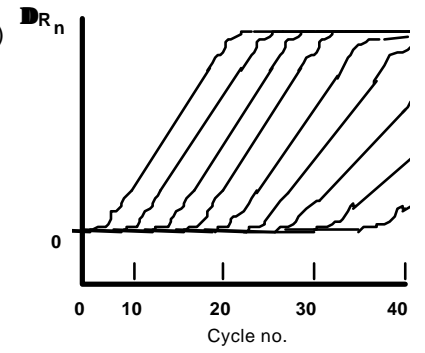

Standard (dilution series)

IIIIIIIII

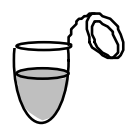

Separate amplifications<smiles>c1ccc(C23CC4CC(C4)C2C3)cc1</smiles>

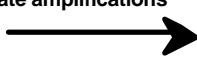


Figure 5. Examples of PCR quantification strategies. In limiting dilution analysis (A), the approximate endpoint is estimated in an initial experiment (1). The number of targets is then calculated from the fraction of positives in diluted, replicate samples in a more extensive experiment (2). In competitive PCR (B), the target is mixed with different amounts of competitor template, by some property distinguishable from the target sequence. The number of initial target molecules is determined from the point in the internal calibration curve where the post-amplification target- and competitor signals are identical. In quantification by kinetic PCR $(\mathbf{C})$, the normalized fluorescence $\bullet R_{n}$ of all samples is determined at least once each amplification cycle, resulting in an amplification plot (1). An external calibration curve (2) is constructed after amplification of a dilution series of a standard of known concentration. The threshold cycle $\left(\mathrm{C}_{\mathrm{T}}\right)$ is the cycle number at which the fluorescence signal of the amplification product exceeds a threshold level of fluorescence. Kinetic PCR quantification is also compatible with the competitive PCR approach, if different FRET-pairs are used.

\section{(II) Competitive PCR}

The most widely used quantification strategy involves co-amplification of the target and known amounts of an internal standard (Becker-André, 1989). (Fig. 5B) Quantitation is achieved by comparing the amounts of the two PCR products formed. Since target and standard usually compete for primers, DNA polymerase and the other components of the reaction mixture, the standard is called competitor and the procedure is termed competitive PCR. Basic considerations when designing a PCR-based competitive assay include (i) design of competitor(s), (ii) simultaneous quantitation of a reference gene, (iii) sensitivity, dynamic range and precision required (iv) quantitation in the exponential or plateau phase, (v) choice of detection method and (vi) quality control. Typically, a fixed amount of the unknown sample is amplified together with a dilution series of the competitor. The competitor differs from the target sequence so that the respective amplicons can be distinguished by for example a slight difference in length (Piatak, 1993), a unique restriction enzyme cleavage site (Becker-André, 1989), a unique sequence for binding of a DNA-binding reporter protein (Lundeberg, 1991) or hybridization to a specific DNA probe (Kohsaka, 1993). The result can be presented as a curve relating $\log$ (competitor signal/target signal) to $\log$ (initial amount of competitor). Provided that the ratios of the amplification efficiencies of the target and competitor remain constant during the amplification, a straight line having a slope of 1 is obtained. 


\section{NYGREN}

To be able to perform absolute and not only relative quantitation, additional experiments are required to make sure of equal amplification efficiencies, since changes in amplification efficiencies not affecting the ratio will lead to a parallel shift of the curve (Raeymaekers, 1993). Equal amplification efficiencies are most likely obtained with competitors as similar as possible to the target sequence (i.e. homologous competitors) (Zimmermann a, 1996). Advantages with heterologous competitors (Siebert, 1992) as opposed to homologous competitors are the lower risk of heteroduplex formation (Hayward-Lester, 1995) which may interfere with the quantification of products, the possibility to quantify several genes with one and the same competitor (Wang, 1989; Tarnuzzer, 1996) and the possibility to include the quantitation of a reference gene, for example a house-keeping gene (Sestini, 1995). Cloned plasmid competitors are convenient in DNA quantitation but in RNA quantitation in vitro transcribed RNA competitors are preferred to control for the large variations in RNA isolation and in the RT step (Piatak, 1993). A way to circumvent the analysis of each sample with a number of competitor dilutions and still keep the benefits of the internal control strategy is to include multiple, distinguishable competitors of different copy numbers and perform the quantitative analysis in a single PCR tube (Vener, 1996; Zimmermann b, 1996). The signals from the competitors are used to construct an internal calibration curve. To improve the sensitivity of a quantitative assay, nested amplification can be used. When quantification is performed in the linear or plateau phase of the amplification (Siebert, 1992; Pannetier, 1993; Morrison, 1994), equal amplification between target and competitor(s) become particularly important, since differences in amplification efficiencies become more pronounced in later PCR cycles (Freeman, 1999; Raeymaekers, 1993). The range within which a reliable quantification can be performed is determined both by the presence of differences in amplification efficiencies (i. e. how large difference in amount of two templates is representatively conserved throughout the amplification) and the dynamic range of the PCR product detection method (i. e. the interval where a linear response is obtained). When highly accurate quantification within a wide dynamic range is desired, the analysis can be performed in a two-step procedure (Souazé, 1996; Freeman, 1999). In the first round, the sample is analyzed with competitors covering the whole relevant interval (perhaps over a range of 5-6 orders of magnitude). In a second step, a more narrow range of standards is used to quantify the 
sample with a high accuracy or to be able to measure small changes between samples. This narrow-range analysis can be performed as a non-competitive assay, i. e. the target signal is unaltered by the standard (Freeman, 1999). The quantification is estimated on a linear-scaled graph and the equivalence point ( $=$ the amount of target) is represented by the intersection of the two lines. The target signal should remain constant and the standard curve should be linear with a slope corresponding to a doubling of the signal as a result of a doubling of standard input.

\section{(III) Kinetic PCR}

A completely different approach to quantitative PCR has emerged during the last years due to technological advances in amplification product detection. The possibility to use amplification reaction kinetics instead of measuring the amount of product accumulated after the amplification was early suggested. However, improvements on both chemistry and instrumentation were required before the use of this technique became applicable. At present, three commercially available systems have been developed to quantify nucleic acid targets by use of reaction kinetics, ABI PRISM 7700 and 5700 Sequence Detection Systems (PE Applied Biosystems), the LightCycler (Idaho Technologies) and the iCycler iQ (Bio-Rad). These instruments detect, quantify and, if necessary, differentiate between products in real time and without opening the tubes. The instrument software transforms amplification plots into linear standard curves (Fig. 5C). Different fluorescence detection principles are now compatible with these instruments. ABI PRISM 7700 originally used hydrolysis TaqMan probes (PE Applied Biosystems) relying on the 5'-->3' exonuclease activity of Taq DNA polymerase. The LightCycler used dsDNA dyes and quantitation by re-hybridization of DNA, enabling single base pair mutant standards to be discriminated by DNA melting curves (Ririe, 1997). The basic difference between kinetic PCR and end-point PCR quantitation is the point in the amplification process where quantitation is performed. In end-point quantitation, all samples are analyzed at a fixed cycle number, where samples containing few copies of the target sequence are still in the exponential phase of the amplification whereas highcopy number samples are detected in the plateau phase. In real-time quantitation, the threshold cycle $\left(\mathrm{C}_{\mathrm{T}}\right)$ is defined as the cycle at which the amplification product reaches a detection threshold and all samples are thereby detected in the exponential phase, where 
inhibition and competition between templates are less pronounced problems (Heid, 1996). The $\mathrm{C}_{\mathrm{T}}$ is inversely proportional to the logarithm of the number of target copies present in the initial sample. A standard curve is constructed by relating the $\mathrm{C}_{\mathrm{T}}$ to the number of starting molecules, using exactly quantified DNA or RNA standards amplified in the same PCR run as the samples. Well-to-well variations of fluorescence can be normalized using a reference dye. To overcome the disadvantages with interpolation of samples to an external calibration curve and reach an absolute quantitation of DNA and to compensate for variable efficiencies in the RT step, addition of an internal (competitive) standard is recommended. Competitive PCR with real-time detection is possible by use of different reporter fluorescent dyes (Gibson, 1996). Target and standard can be detected in the same tube or, if a wide dynamic range is required and overlapping spectra is a problem, in duplicate reactions containing both target and standard but only one of the two detection probes. Additional advantages with kinetic analysis, except from the exponential phase detection, include fewer manipulations enabling high throughput systems and no post-PCR sample handling reducing the risk of contamination. A consequence of the sensitive detection system is that only a single round of amplification is required to quantity within a wide dynamic range. The visualization of the amplification process itself, including within-cycle monitoring can be useful in the PCR optimization process and provide indication of inhibition of the amplification in clinical samples.

\subsection{DNA sequence determination}

During the last twenty years, several techniques for determination of the exact nucleotide sequence of a DNA molecule have been developed. The most used one is Sanger's dideoxy chain termination method (Sanger, 1977), in which four sets of terminated, labeled DNA fragments of different lengths are synthesized by a DNA polymerase and separated by gel electrophoresis (illustrated by solid-phase sequencing (Hultman, 1989), Fig. 6A and cycle sequencing (Carothers, 1989; Innis, 1988), Fig. 6B). Mass spectrometry can be used for mass analysis of Sanger fragments (Jacobson, 1991) or by performing a dissociation-based sequencing reaction in the mass spectrometer (Little, 1995). In chemical and enzymatic degradation techniques, the terminally labeled DNA molecules are fractionated in four nucleotide-specific reactions (Maxam, 1977). A 
completely different approach is sequencing by hybridization (Bains, 1988), detecting perfect complementary between the DNA molecule to be sequenced and oligonucleotides attached to a high density DNA array (Drmanac, 1998). In sequencing-by-synthesis, nucleotides are detected as they are incorporated during a primer-directed DNA polymerase extension (exemplified by pyrosequencing (Ronaghi, 1998), Fig. 6C). Despite the rapid development in sequence-based technology, DNA sequencing is still rather expensive.

In the detection and analysis of infectious agents, DNA sequencing is primarily used in the discovery and identification of microorganisms or antibiotic resistanceencoding genes. "New" pathogens have been identified both by using broad range PCR (Wilson, 1994) and by using representational difference analysis (RDA) of diseased and normal tissue (Chang, 1994). When the obtained sequence is aligned with previously known sequences, phylogenetic relationship can often be inferred. From the sequence data, a specific assay for detection of the pathogen might be developed, to be used in diagnostics and to study the epidemiology and ecology of the pathogen. The phylogenetic relatedness can also be used to suggest suitable culture conditions for isolation of the organism and potentially also antigenic relatedness for the development of immunodiagnostic tests (Dumler, 1995). Alternatively, pathogen-specific, antigenencoding sequences recovered from diseased tissue can be cloned and expressed, allowing immunodiagnostic tests to be developed for organisms not yet isolated by culture (Feldmann, 1993). DNA sequencing to detect antibiotic resistance as well as the dynamic changes in viral drug resistance can also often be translated into simpler tests (see above). 


\section{NYGREN}
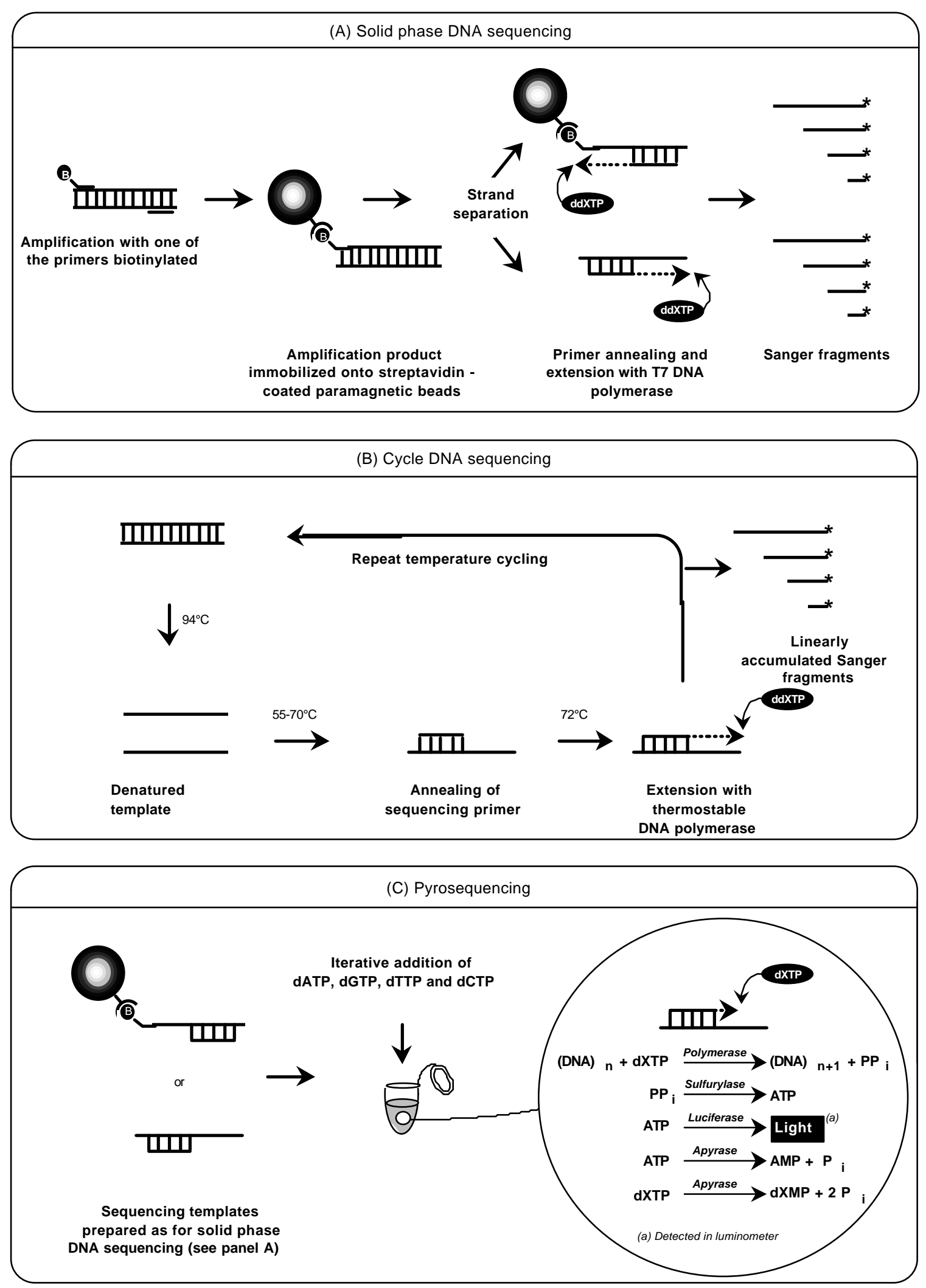


\section{MOLECULAR DiAGNOSTICS OF INFECTIOUS DISEASES}

Figure 6. Examples of DNA sequencing techniques. Solid-phase Sanger sequencing (A) of PCR products was developed to allow automated sequencing of both DNA strands separately, and to facilitate change of reaction buffers by using super-paramagnetic particles and the highly stable streptavidin-biotin interaction. The Sanger fragments generated in cycle sequencing (B) are synthesized by a thermostable DNA polymerase during thermal cycling. In pyrosequencing (C), unlabeled nucleotides are added iteratively to the primed template in a four-enzyme mixture. Correct nucleotides are incorporated by the polymerase and PPi release is detected by the actions of ATP sulfurylase and luciferase. Excess of nucleotides or nucleotides not complementary to the template are degraded by apyrase. 


\section{PRESENT INVESTIGATION}

\section{Diagnosis of Bordetella infection by PCR (I-IV)}

\subsection{Pertussis and laboratory diagnosis of Bordetella infection}

Of the six to date known species of the genus Bordetella, only three are normally associated with human illness; $B$. pertussis causing classical whooping cough, $B$. parapertussis causing pertussis-like disease and the less frequently occurring $B$. bronchiseptica causing respiratory disease also in other mammals. When these three species were first investigated by DNA analysis their close genetic relatedness raised the question whether they actually were three separate species or represent only different subspecies (Musser, 1986). However, further analysis by DNA restriction profiles, analysis of LPS and the lack of cross protection after infection or immunization with one of the species confirmed the differentiation into three separate species (Khattak, 1993; Amano, 1990).

Pertussis is a highly contiguous disease, in its typical form characterized by a catarrhal, a paroxysmal and a convalescent stage. The virulence factor traditionally believed to be responsible for the classical symptoms of whooping cough is pertussis toxin (PT) (Pittman, 1979), considered only to be produced by B. pertussis, even though the PT promoter as well as the structural genes are present also in the other two species. Since the earlier widely used whole-cell vaccines suffer from poor potency and frequent side reactions, alternative component vaccines have been developed and tested during recent years (Marwick, 1995; Schmitt-Grohe, 1995; Trollfors, 1995).

To avoid spread of pertussis and to efficiently reduce the symptoms of the disease by antibiotic treatment, rapid diagnostic procedures are required. In epidemiological studies and in vaccine efficacy trials, differentiation between the species is of interest. Since the pathogen rapidly looses its viability outside the body and is fastidious about growth conditions, optimal sampling, transport conditions and processing of samples are necessary. The golden standard in laboratory diagnosis of pertussis is culture (Müller, 1997). In combination with biochemical analysis, the specificity is high and differentiation between Bordetella species is possible, but the sensitivity is only about 50 
$\%$ (Onorato, 1987) and culture takes 3 to 12 days to complete (Katzko, 1996). In epidemiological studies, serology is a valuable diagnostic method, but in vaccine studies it is important to be able to distinguish between Bordetella infection and vaccine effects (Mink, 1994). Since acute and convalescent sera are preferred, rapid diagnosis early in the disease is difficult with serology.

As an alternative to culture, different regions in Bordetella spp. DNA have been used as targets in diagnostic PCR, such as insertion sequences (Glare, 1990; He, 1993; Houard, 1989; Lichtinghagen, 1994; Olcen, 1992; van der Zee, 1993), the adenylate cyclase gene (Douglas, 1993), the porine gene ( $L i, 1994)$ and the pertussis toxin (PT) promoter region (Houard, 1989; Reizenstein, 1993; (I); Stefanelli, 1996). An advantage using the PT promoter is the possibility to amplify B. pertussis, B. parapertussis and $B$. bronchiseptica in a single PCR with generic primers with subsequent differentiation between the three species by restriction analysis of the PCR amplicons. A comparison between the different PCR assays is difficult, since they use different reference methods and study populations, different sampling and processing methods and report varying rates of false positive samples. However, most assays are able to detect single organisms but show less than $100 \%$ sensitivity when compared to culture, probably illustrating the fact that the sample preparation method is critical for the diagnostic sensitivity of the PCR (Müller, 1997). The two main factors are yield of bacterial DNA from the sample and occurence of $T a q$ DNA polymerase inhibiting factors in the clinical sample. The most frequently used methods to enrich and purify the target prior to pertussis PCR include centrifugation to pellet the bacteria, repeated washing of the bacteria if the sample contained blood, ultrasonication, treatment with mucolytic agents or proteinase $\mathrm{K}$ or cation exchange treatment, phenol-chlorophorm extraction of DNA or just a simple boiling of the sample (Meade, 1994; Muller, 1997). 


\section{NYGREN}

\subsection{Solid-phase sample preparation and detection of Bordetella (I)}

The aim of this study was to evaluate if immunomagnetic separation of intact (fresh or frozen) Bordetella bacteria can replace the previously used PCR sample preparation method based on centrifugation, repeated washings if the sample contained blood, Proteinase $\mathrm{K}$ treatment and boiling. To avoid PCR product analysis by gel electrophoresis, a solid-phase detection assay, DIANA (Detection of Immobilized Amplified Nucleic Acids) was combined with restriction analysis to allow differentiation between Bordetella species in an enzyme-linked immunosorbent assay (ELISA) format (Fig. 7). The paramagnetic support allows for rapid capture of target organism, complete removal of inhibitors and change of reaction buffers by magnetic separation, enables enzymatic manipulations to be performed on immobilized nucleic acid and facilitates automation.
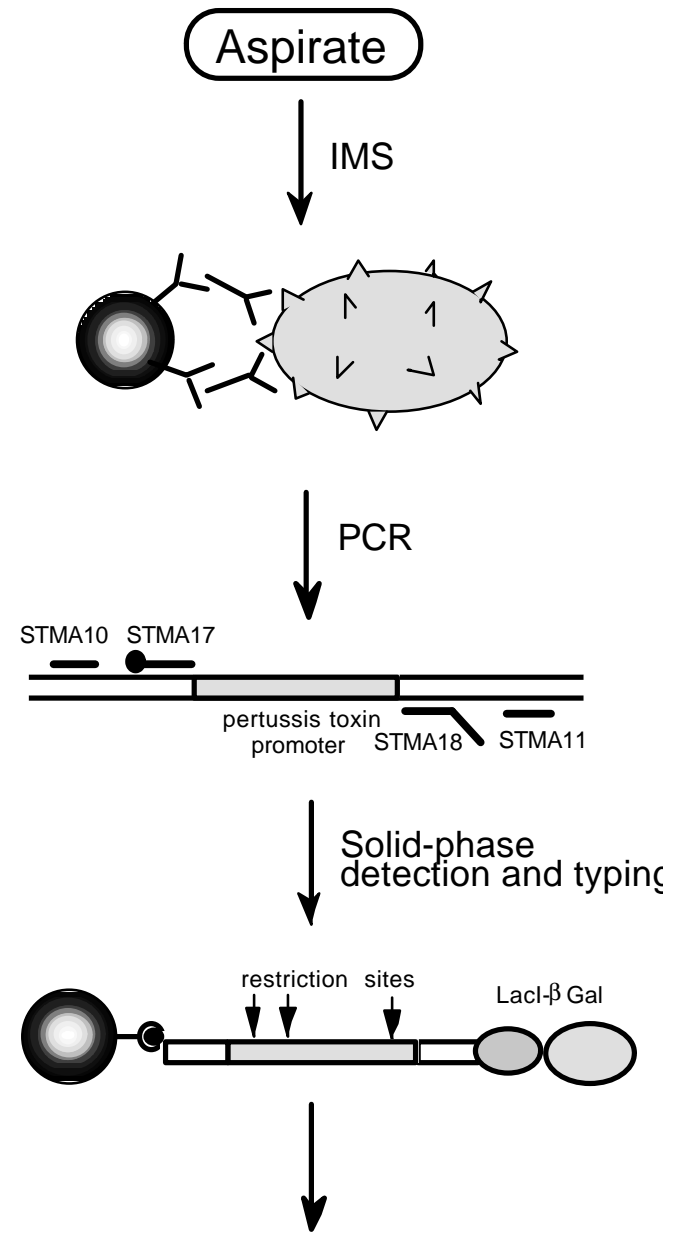

Colorimetric detection (DIANA) 
Figure 7. The integrated concept consists of (i) immunomagnetic separation (IMS), (ii) PCR, (iii) detection of immobilized amplified nucleic acid (DIANA) in an enzyme-linked immunosorbent assay (ELISA) format, together with, (iv) typing of bacteria by restriction enzyme analysis

Immunomagnetic separation of bacteria was performed by using two polyclonal rabbit sera directed against B. pertussis and B. parapertussis, respectively, as primary antibodies, bound to a secondary anti-rabbit antibody which were covalently coupled to the magnetic bead. The enriched and purified bacteria were simply lyzed by an intial heat denaturation cycle prior to the PCR program. A 300-bp long fragment of the PT promoter region was amplified using two sets of oligonucleotide primers in a nested procedure, incorporating biotin and the lac operator sequence into the PCR amplicons. Following PCR amplification, simultaneous binding of PCR product onto streptavidin-coated magnetic beads and binding of the recombinant lac repressor- $\beta$-galactosidase fusion protein was performed. Positive samples, with the lac operator sequence incorporated by PCR, were colorimetrically detected after addition of chromogenic substrate. Furthermore, the assay was combined with species identification based on restriction enzyme analysis of positive samples. The PCR amplicons immobilized onto the solid support were separately treated with three different restriction enzymes allowing a colorimetric determination of Bordetella species in a given sample. Restricted fragments resulted in little or no signal since the lac operator was removed by magnetic separation and the intact fragments resulted in a strong colorimetric response. Fifty-five frozen nasopharyngeal aspirate samples from patients participating in a phase 3 pertussis vaccine efficacy trial and with suspected pertussis infection were analyzed in a blinded fashion test. The samples were analyzed in parallel by culture and the clinical history and vaccination status of the patients was known. Among the 22 samples from which B. pertussis was isolated by culture, 21 samples were positive by IMS-PCR-DIANA (95\%). The growth estimates showed that this group of samples contained samples with both few and many viable bacteria. Two samples were negative by culture, but showed to be positive when analyzed by the PCRbased assay. Unfortunately, serology results were missing for both these patients, but they had a duration of paroxysmal cough of 29 and 55 days respectively, which should be 
compared to the minimal criterium of -21 days for pertussis, which was used within the trial, in accordance with a WHO consensus meeting (WHO, 1991). One culture-positive sample was negative by PCR. This patient was positive for B. pertussis also by serology, but had no paroxysmal cough. The duplicate sample analyzed by culture contained few bacteria, corresponding to $3 \mathrm{CFU}$. This unexpectedly missed sample stresses the fact that homogenous samples are difficult to achieve making comparisons between different methods somewhat difficult. Restriction enzyme typing of amplicons showed that all samples were of $B$. pertussis origin and no mixed infections were observed. This was in accordance with the culture results.

\subsection{Sequencing of a pertussis toxin promoter region used in DNA-based diagnosis of Bordetella infection (II, III)}

In recent years, studies involving genetic and functional analysis of the PT promoter and its regulation have resulted in publications of several PT promoter sequences. Some of these sequences differ from the first described B. pertussis, B. parapertussis and B. bronchiseptica PT promoter sequences, used in the design of PCR primers and in the choice of restriction enzymes for typing (see above). Therefore, we decided to undertake sequence analysis of the promoter region used by us to detect and distinguish between B. pertussis, B. parapertussis and B. bronchiseptica. The goal was to investigate whether amplification with generic primers and subsequent restriction analysis can be used to reliably identify the three species. In addition, clinical isolates from samples originally negative in a PT promoter PCR directly on nasopharyngeal aspirates but positive in culture were analyzed. Another objective was to investigate if DNA sequence polymorphism could explain the lower diagnostic sensitivity obtained for patients with $B$. parapertussis infection than for patients with $B$. pertussis infection in a validation of a nested PT promoter PCR in a pertussis vaccine trial (Reizenstein, 1996).

When analyzing a total of 33 ATCC type strains and clinical isolates, we experienced technical difficulties in determining the nucleotide sequence in part of the sequenced region. All strains were sequenced by conventional Sanger DNA sequencing by one or more strategies including (i) a solid-phase method involving FITC-labeled terminators and T7 DNA polymerase, (ii) a cycle sequencing protocol involving Cy5labeled terminators and ThermoSequenase DNA polymerase or (iii) cycle sequencing 
with Cy5-labeled primers and ThermoSequenase DNA polymerase. The best result was obtained when dye-primer cycle sequencing was performed and the Sanger fragments were analyzed at high gel temperature. However, a short region of the sequence remained difficult to resolve (especially pronounced in all the $B$. parapertussis strains and in $B$. bronchiseptica strain ATCC 19395) due to sequence compressions. These problems being the result of strong secondary structures that cause band compressions during electrophoresis of the Sanger fragments. Therefore, we employed an alternative non-gel based sequencing method, pyrosequencing, to resolve the sequence in this region. This sequencing-by synthesis method is based on coupled enzymatic reactions, which transform the inorganic pyrophosphate (PPi) released when a nucleotide is incorporated into the primed singel-stranded template into a light signal, which can be detected by a photon detector device. By use of biomagnetic separation during preparation of the sequencing template, bi-directional pyrosequencing can be performed (Fig. 6C). The polymerase dependent contribution of strand-displacement activity in primer extension through self-complementary regions was investigated by performing pyrosequencing with three different DNA polymerases. The results showed that the activity of exonuclease-deficient (exo-) Klenow DNA polymerase (that possesses a strong stranddisplacement activity) was comparable to the activity on a "normal" template. An exomutant of $\phi 29$ DNA polymerase, which is deficient in strand-displacement activity, was unable to read through a hairpin structure. An exo- T7 DNA polymerase (Sequenase) showed a relatively high catalytic activity on this template. The results obtained by bidirectional pyrosequencing using exo-Klenow polymerase revealed repeated sequences able to form stable palindromic hairpin structures in the strains showing strong compressions in Sanger sequencing. The pyrosequencing result for these strains was confirmed by sequencing of a synthetic template containing the same structural motifs, resulting in identical pyrosequencing data. 


\section{NYGREN}

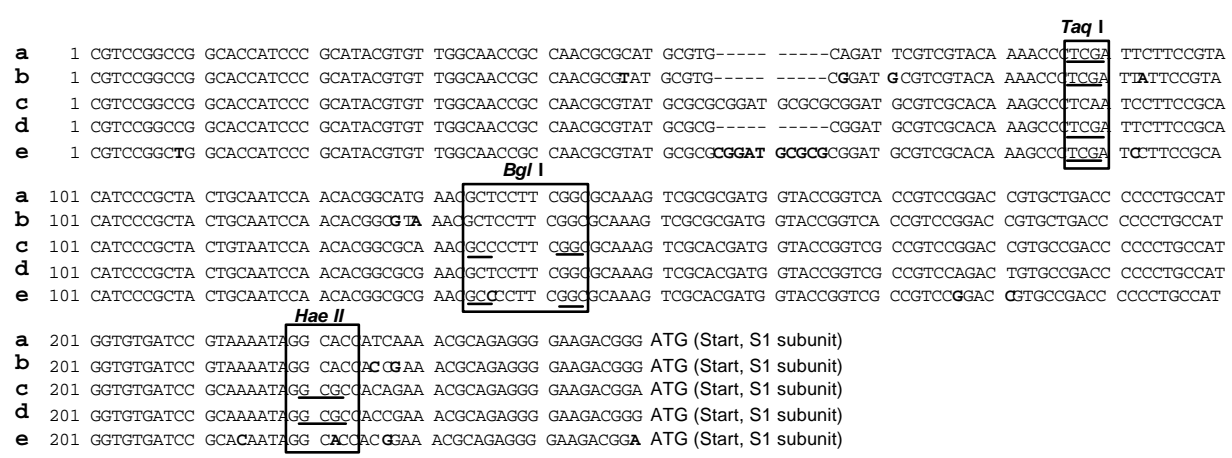

Figure 8. The five different sequences encompassing the 239 or 249 nucleotides upstream of the start codon of the PT subunit 1 gene found among the 33 ATCC reference strains and patient isolates sequenced. The three restriction sites used for species identification are marked with boxes. Restriction enzyme recognition sequences are underlined. The nucleotide positions in sequence b (B. pertussis ATCC 9797 and 9340) that are different from those in sequence a (B. pertussis patient isolates) are marked in boldface. The nucleotide positions in sequence e (B. bronchiseptica ATCC 19395) that differ from those in sequence $d$ (B. bronchiseptica ATCC 786 and AB1254) are also marked in boldface. Sequence $c$ is the sequence common to all of the B. parapertussis strains.

After alignment of the sequences obtained in these two studies (Fig. 8), we compared the sequences to the PT promoter sequences available in the public databases and focused on the restriction enzyme recognition sequences used for species differentiation. A number of nucleotide differences not affecting the restriction analysis using TaqI, BglI and HaeIII were observed. However, B. bronchiseptica ATCC 19395 contains the previously considered $B$. parapertussis-specific $B g l$ I recognition sequence in addition to the expected Taq I site. The Hae II site, present in the other $B$. bronchiseptica strains, is disturbed by a G-A polymorphism (sequence e in Fig. 8). B. bronchiseptica ATCC 19395 differ also from the other two B. bronchiseptica sequences by containing the $10 \mathrm{bp}$ insertion present in $B$. parapertussis and by having nine nucleotide substitutions (marked in bold in sequence e, Fig. 8) compared to the other $B$. bronchiseptica strains. Since the database sequence most similar to $B$. bronchiseptica ATCC 19395 was a $B$. parapertussis strain, we decided to investigate $B$. bronchiseptica ATCC 19395 further. Strain 19395 was identified at the Culture Collection, University of Gothenburg, Sweden as Bordetella bronchiseptica by use of 103 classical biochemical features and numerical analysis. 
In summary, a total of five different sequence types for the pertussis toxin promoter region and four different restriction patterns were found among the 33 strains analyzed (Fig. 8). To confirm the restriction sites found by sequencing, we performed the previously described colorimetric restriction analysis of PCR products (Fig. 9).

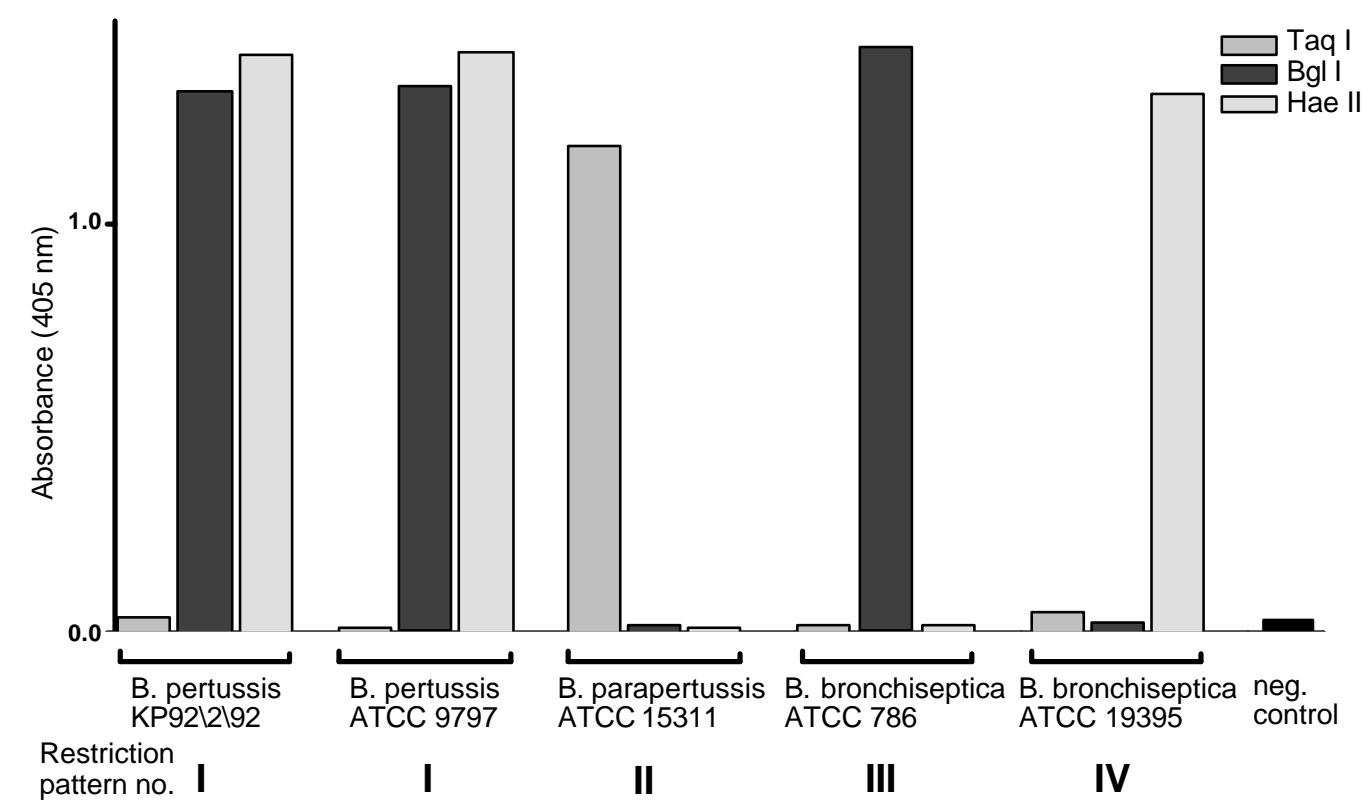

Figure 9. Results from colorimetric restriction enzyme analysis of Bordetella strains representing the five different PT promoter sequence types to confirm the four restriction patterns revealed in Fig. 8.

Thus, according to the PT promoter sequences available today, restriction analysis of amplicons from the promoter region using Taq I, BglI and Hae II results in identification of the three species. In addition, the results indicate that the two different $B$. bronchiseptica sequence variants can be distinguished by restriction analysis. Alternatively, the five different sequence types could be identified by designing a sequencing primer (which hybridizes to nucleotides 113 to 90 in Fig. 8) and performing pyrosequencing to determine at least 32 bases that could distinguish between species. In conclusion, the results of this study indicate that the PT promoter region can be used for reliable discrimination between the three major Bordetella species causing human infection. However, the findings in this study justify further sequence analysis of isolates from cases with contradictions in biochemical and serological reactions and clinical history. 


\subsection{Quantification of Bordetella pertussis (IV)}

Traditionally, the diagnosis of pertussis is only a qualitative determination, providing a yes or no answer. A quantitative assay might be valuable primarily as a research tool, to provide some additional insight into the host-parasite relationship during clinical and subclinical infections. The number of bacteria could be determined and potentially be related to clinical symptoms, sampling time, treatment with antibiotics and vaccination status etc. For this purpose, a competitive nested PCR assay with DIANA detection was developed.

In this study, the target sequence amplified by PCR was located within the insertion sequence IS 481, present in approximately 70-80 copies per bacterial cell of $B$. pertussis only. A PCR competitor plasmid containing the lac operator sequence was constructed and used in a competitive PCR designed to quantify between $10^{2}$ and $10^{7}$ bacteria/ml with PCR product detection by DIANA. The assay was evaluated by analysis of a total of 46 nasopharyngeal aspirate samples, which were vortexed and boiled for 30 min before amplification of an aliquot with nested primers. Semiquantification by culture and a standard qualitative PCR were performed in parallel. In 7 of the 23 samples that were positive both by culture and by the quantitative PCR, the $\mathrm{CFU} / \mathrm{ml}$ was too high to be counted (no dilutions of the aspirate samples were cultured). In one single case the quantitative estimation by PCR was lower than with quantification by culture. In the remaining samples, the number of bacteria quantified by PCR was 1.5 to 233 times higher than the viable count determined by culture. The intra- and inter assay variations for the quantitative PCR-DIANA assay were estimated to be up to 24 and $66 \%$ respectively. The intra-assay variation was found to be up to $48 \%$ for quantification by culture.

A second aim of the quantitative assay was to identify samples containing strongly inhibitory substances. This is possible since the PCR competitor being present serves as an internal PCR control. No such samples were identified in this study. However, a discrepancy between the results obtained with the qualitative PCR and the quantitative PCR assay was observed. Four samples that were negative by qualitative PCR were determined to contain between 30 and 60 bacteria/ml by the quantitative PCR. This might be the result of weak PCR inhibitory effects, resulting in a reduced absorbance mainly in the dilution with the lowest competitor concentration 
(corresponding to $30 \mathrm{bacteria/ml),} \mathrm{thereby} \mathrm{making} \mathrm{it} \mathrm{difficult} \mathrm{to} \mathrm{distinguish} \mathrm{between}$ negative samples containing inhibitory substances and low-copy positive clinical samples. Another explanation could be the difficulty to mix and aliquot the sometimes inhomogeneous samples (indicated by the high $\mathrm{CV}$ obtained also for quantification by culture), most obvious with samples containing low amounts of targets.

In conclusion, the amount of $B$. pertussis target DNA present in an aspirate sample is probably higher than the number of viable bacteria. If quantification of live bacteria is satisfactory or preferred for study of patient-bacterium relationship, this can be achieved by culture of the sample and of one or two dilutions of the aspirate. The superior benefit from pertussis diagnosis by PCR is probably the high sensitivity obtained in combination with the rapidness of a qualitative assay. To avoid and identify false negative samples due to inhibition of PCR, a sample preparation method involving removal of the inhibitors and possibly amplification of an internal PCR control can be an alternative. 


\section{PCR-based detection of Vibrio cholerae 0139 Bengal (V)}

\subsection{Background}

Until 1992, Vibrio cholerae serogroup O1 was the only etiological agent recognized causing epidemic cholera, while non-O1 serotypes were only associated with smaller, local outbreaks of cholera. Of the seven cholera pandemics so far recorded, the last three ocurred when typing of microorganisms had become feasible and were determined to be caused by $V$. cholerae O1. In the beginning of 1992, a new strain not related to the by then known 138 serogroups spread rapidly through India and Bangladesh, into neighbouring countries and imported cases were reported also from other continents. The new epidemic species V. cholerae O139 Bengal causes a disease indistinguishable from classical cholerae and was predicted to have the potential to cause an eighth cholerae pandemic, since aquired immunity to cholerae caused by $V$. cholerae O1 does not protect against cholerae caused by V. cholerae O139 Bengal (Albert, 1994).

A large number of studies have been performed to characterize this novel serotype. V. cholerae O139 Bengal was found to be morphologically and biochemically similar to $V$. cholerae $\mathrm{O} 1 \mathrm{El}$ Tor, associated with the seventh pandemic. However, in contrast to $V$. cholerae $\mathrm{O} 1$ but similar to many non-O1 serogroups, $V$. cholerae $\mathrm{O} 139$ Bengal possesses a polysaccharide capsule (Johnson, 1994). The capsule is suggested to confer increased virulence, possibly facilitating invasion and bacteremia and potentially also an increased ability to survive in the aquatic environments which constitute the main reservoir for vibrios (Mooi, 1997). Another difference revealed was an altered LPS antigen structure including the $\mathrm{O}$ antigen. When the $\mathrm{O} 139$ Bengal $r f b$ gene cluster responsible for $\mathrm{O}$ antigen biosynthesis was investigated, new genes for $\mathrm{O}$ antigen and capsule polysaccharide synthesis, assembly and transport seem to have been aquired by horizontal gene transfer to replace the corresponding V. cholerae $\mathrm{O} 1$ genes (Comstock, 1996; Stroeher, 1997).

The traditional stool culture technique for cholera diagnosis takes approximately two days to complete and include culture on selective medium, analysis of biochemical reactions and agglutination with absorbed polyclonal sera or monoclonal antibodies to confirm serotype. Several methods have recently been described for detection of both etiologic agents today known to cause cholerae and by some of the methods, 
differentiation between $V$. cholerae $\mathrm{O} 1$ and $V$. cholerae $\mathrm{O} 139$ is possible. Co-infection with vibrios of both serogroups has also been reported to occur ocasionally (Sharma, 1998). Slide agglutination tests with polyclonal sera were first used to identify $V$. cholerae O139 in colonies and directly in stool samples (Albert, 1994). A diagnostic kit (Bengal SMART) based on monoclonal antibodies has been developed for rapid and specific detection of V. cholerae O139 Bengal (Qadri, 1995). A CAMP hemolysin test has also been evaluated for differentiation between $V$. cholerae O139 Bengal and $\mathrm{O} 1$ (Lesmana, 1996). DNA probes have been used in a colony hybridzation approach to identify V. cholerae O139 Bengal (Nair, 1995). Today, a number of PCR assays have been developed to identify $V$. cholerae O139 Bengal, also a multiplex PCR for detection of toxigenic $V$. cholerae $\mathrm{O} 1$ and $\mathrm{O} 139$ by co-amplification of serogroup-specific regions of the $r f b$ cluster and $c t x A$, encoding the toxic subunit of cholera toxin (Hoshino, 1998).

\subsection{Isolation and characterization of a Vibrio cholerae 0139 Bengal- specific DNA region $(\mathrm{V})$}

When the V. cholerae O139 Bengal polysaccharide capsule was analyzed, it was found to contain the rare sugar colitose, absent from $V$. cholerae O1. The biochemical pathway of colitose is not completely known, but the very similar sugar tyvelose is present in certain Salmonella serogroups and could theoretically be transformed into colitose by an epimerase. Since the sequences of the $r f b J, r f b S$ and $r f b E$ genes involved in the synthesis of abequose, paratose and tyvelose are known (Verma, 1989), we wanted to investigate whether $V$. cholerae O139 Bengal contains a gene analogous to the Salmonella $r f b S$ gene. By arbitrary PCR $(L u k, 1993)$ with primers complementary to the Salmonella $r f b S$ gene we isolated a 693 bp region (Fig. 10), surprisingly showing no similarity to the Salmonella sequence. A restriction fragment length polymorphism including Southern blot analysis with the Salmonella $r f b S$ PCR product as probe also indicated that the Salmonella rfbS gene was not present in V. cholerae O139 Bengal. 


\section{NYGREN}

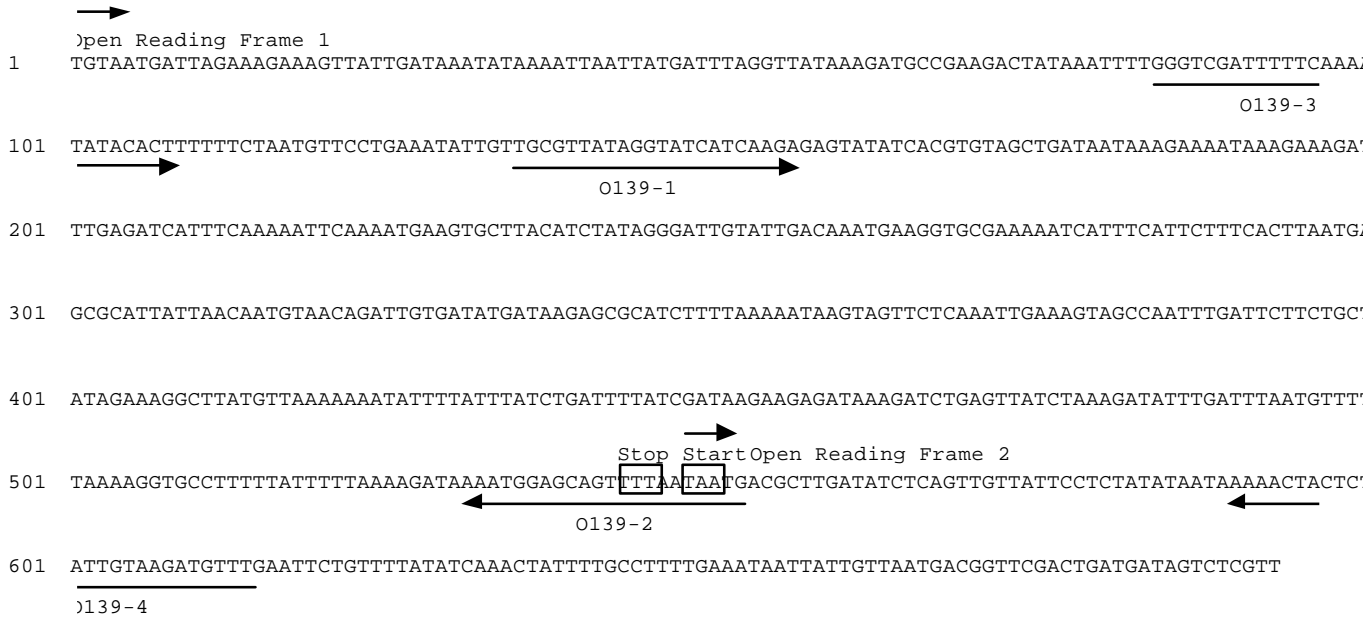

Figure 10. DNA sequence of the V. cholerae O139 Bengal PCR fragment obtained with Salmonella rfbS primers. The two open reading frames are marked and the four $V$. cholerae $\mathrm{O} 139$ Bengal PCR primers are indicated by arrows.

The DNA sequence of the fragment obtained by arbitrary PCR was translated into amino acid sequence (Fig. 11) and a database search revealed significant similarity of the two open reading frames to glycosyltransferases from different bacterial species (Fig. 11).

Open Reading Frame 1
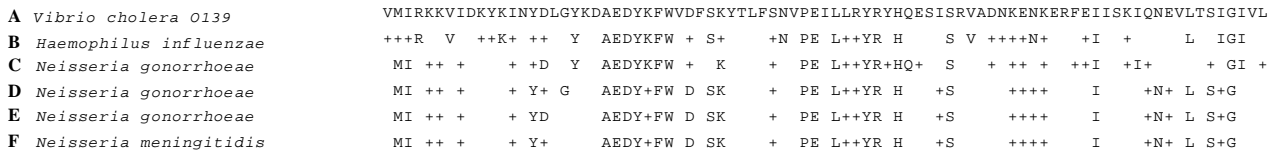

Open Reading Frame 2

A Vibrio cholera 0139

G Escherichia coli

H Yersinia enterocolitica

I Shigella dysenteriae

B Haemophilus influenzae

E Neisseria gonorrhoeae

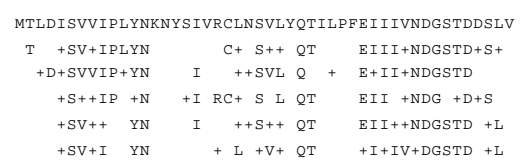

Figure 11. Deduced amino acid sequences of the two open reading frames are aligned with some of the similar protein sequences found in databases by using BLAST software. + , a similar amino acid as defined by the software. The first amino acids correspond to nucleotide 2 to 4 (valine in open reading frame 1) and 550 to 552 (methionin in open readingframe 2) in Fig. 10. Sequences B; C; D; E, and F are identified as glycosyltransferases, sequence $\mathrm{G}$ is identified as a $40.5-\mathrm{kDa}$ hypotetical protein, and sequence $\mathrm{I}$ is identified as a galactocyl transferase. 
Since the isolated fragment was not obtained by amplification of $V$. cholerae $\mathrm{O} 1$ with Salmonella $r f b S$ primers, the sequence could be unique for the O139 serotype and might therefore be used in specific diagnosis of $V$. cholerae O139 Bengal. To investigate this further, a primer pair complementary to the new V. cholerae O139 Bengal sequence was synthesized (Fig. 10). The specificity of the primers was evaluated on a total of 418 strains. The $34 \mathrm{~V}$. cholerae $\mathrm{O} 139 \mathrm{Bengal}$ strains tested were positive whereas none of the 384 control strains were positive. To be able to perform a sensitive and specific analysis of clinical and environmental samples suspected to contain low amounts of $V$. cholerae O139 Bengal, a nested PCR assay was developed by designing an outer primer pair (Fig. 10) in addition to the previously evaluated inner primers. The nested PCR was able to detect single $V$. cholerae O139 Bengal bacteria in a serially diluted bacterial lysate.

The developed assay was the first reported PCR assay specific for $V$. cholerae O139 Bengal and it has been used for specific detection of $V$. cholerae O139 Bengal in clinical samples (Albert a, 1997) as well as in environmental water samples (Falklind, unpublished).

\subsection{Future analysis of $V$. cholerae 0139 Bengal isolates}

After the first outbreaks in 1992, the $V$. cholerae O139 Bengal fraction of the $V$. cholerae isolates collected in Bangladesh and India continued to grow during 1993 and almost replaced the serogroup O1, but during 1994 and 1995 V. cholerae O1 El Tor reemerged and transiently displaced the $\mathrm{O} 139$ vibrios to again become the dominant strain in most regions (Mitra, 1996; Faruque, 1996). The reemerging El Tor vibrios were characterized by detailed analysis of several genes, resulting in the conclusion that the reemerged strains represent a new clone of El Tor vibrios, different from those which were replaced by V. cholerae O139 Bengal in 1992 (Faruque, 1997). However, during 1995 and 1996, the incidence of V. cholerae O139 Bengal increased again to coexist with the El Tor vibrios in Bangladesh and India (Mitra, 1996). The molecular characterization of these isolates suggests that they represent a new clone of the Bengal vibrios (Faruque, 1999). Changes in antibiotic susceptibility have been demonstrated (Mitra, 1996) and the CAMP hemolysin test does not distinguish V. cholerae O139 Bengal isolated after the middle of 1995 from $V$. cholerae O1 (Albert b, 1997). However, the PCR assay described above $(\mathbf{V})$ is positive also for recent isolates. The recently recognized cyclic changes of 


\section{NYGREN}

predominant serotype in cholerae epidemics of Southeast Asia need to be studied in more detail. Both clinical and environmental surveillance and molecular fingerprinting of $\mathrm{O} 1$ and O139 clones are probably important both to design effective cholera vaccines (Arya, 1997; Waldor, 1994) and to predict and circumvent outbreaks of cholera epidemics in the future (Mooi, 1997). 


\section{PCR quantification of human immunodeficiency virus type 1 (VI-VII)}

\subsection{Background}

The clinical syndrome later known as aquired immunodeficiency syndrome (AIDS) was first described in 1981 (Control, 1982). However, retrospective studies have shown that AIDS was widely spread long before 1981, with serology-confirmed infection in central Africa already in 1959 (Nahmias, 1986). Since then, the human immunodeficiency virus (HIV) (Barré-Sinoussi, 1983), the causative agent of AIDS, has infected more than 50 million people and has caused approximately 16 million deaths, and the AIDS pandemic is still growing.

The HIV-1 virus replicates rapidly in vivo, with short half-life for both plasma virus and virus-producing cells (Perelson, 1996). Together with the low-fidelity replication by HIV-1 reverse transcriptase (RT), this results in a rapid evolution and selection of HIV-1 quasispecies into dominating, drug-resistant variants (Wei, 1995). Therefore, treatment with a combination of multiple viriostatics is used today, to achieve a rapid decrease in viral load and to avoid development of viral drug resistance (Colgrove, 1999; Mathe, 1999).

In addition to detection of drug-resistant HIV-1 variants (Ballard, 1998), nucleic acid-based analysis is applied in the qualitative detection of HIV-1 RNA in pools of donated blood, to reduce the risk of viral transmission in the time interval in which HIV-1 infected donors are highly infectious but do not have any detectable antigens (Morandi, 1998). Quantitative analysis can be applied to analyse the amount of HIV-1 DNA in different tissue reservoires during latent infection (Chun, 1997). However, important is also the quantitation of HIV-1 viral load (Clarke, 1999), with implications in monitoring of antiretroviral therapy, detection of emerging drug resistance and in assessment of disease prognosis (Hodinka, 1998; Mellors, 1996). Different nucleic acid amplificationbased methods have been used for sensitive and accurate quantification ov HIV-1 viral load (Hodinka 1998) and several tests are commercially available (Lin 1998). 


\subsection{Quantification of HIV-1 using multiple PCR competitors and gel electrophoresis (VI)}

A major disadvantage of the commercial assays for quantification of HIV-1 and other pathogens is their high cost. Furthermore, they are still available only for a limited number of organisms. The introduction of real-time, homogeneous quantitative PCR (see above) has enabled high-throughput quantification assays to be developed for a wide range of pathogens. However, for kinetic analysis these methods require expensive instrumentation and / or costly probes. Consequently, alternative competitive PCR assays are still developed. These usually make use of co-amplified PCR competitors, slightly different in sequence from the target to be quantified, and quantification of the resulting PCR products by different methods (see above).

In this study (VI), we wanted to improve a recently described single-tube format for quantification of HIV-1 DNA, which is based on the use of three, different sized competitors in a single reaction tube (Vener, 1996). The post-PCR analysis and quantification is performed by conventional gel electrophoresis using an automated laser fluorescent DNA sequencer. The peak areas of the competitors are used to construct the internal calibration curve for estimation of the target copy number. In this study, we have described a sensitive RT-PCR assay (Fig. 12) with four RNA competitors differing in size but containing the same primer annealing sequences as the wild-type target. We prepared HIV-1 RNA from plasma samples by a sensitive solid phase technique (Albert, 1992), enabling capture of down to a few competitor RNA molecules. Since the RNA competitors also comprised of a poly(A) stretch, various possibilities were evaluated in respect to solid phase purification, i.e. poly(A)poly(T) hybridization. The experiments performed to analyze RT and PCR amplification efficiencies showed that the ratios between competitors and target were kept during RT, outer and inner PCR. 


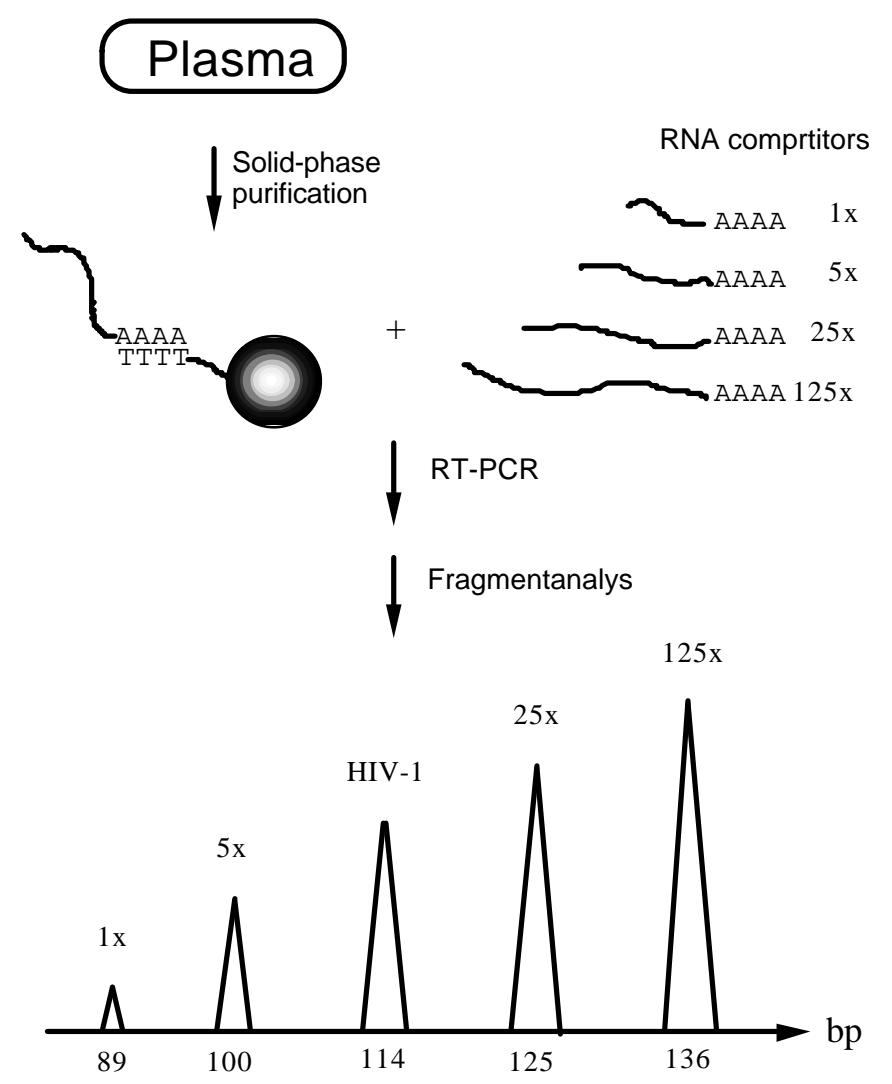

Figure 12. The basic concept of the competitive approach for quantification of HIV-1 RNA in plasma. The mixture of amplicons resulting from the single-tube RT-PCR is analyzed by conventional gel electrophoresis using an automated laser fluorescent DNA sequencer. The peak areas of the competitors are used to construct an internal calibration curve for estimation of the target copy number.

A common problem with competitive PCR is that the detection principle often suffers from a limited dynamic range. Automated fluorescence-based sequencers, which we used, usually have a working dynamic range of $10^{2}-10^{3}$-fold, and signal values that are higher than this range are displayed as truncated peaks in chromatograms. To circumvent this problem and to produce peaks that can be reliably used in creation of a calibration curve, we used two overlapping sets of RNA competitor mixtures which together covered the interval between 40 and 500,000 copies of HIV-1 RNA. In addition, different amounts of PCR product were loaded on the polyacrylamide gel.

An important aspect of any quantification system is the precision of the assay and, in this respect, our assay compares well with commercial assays. Thus, the pooled duplicate standard deviation of log copies obtained for the overall procedure was 0.13 
$(\mathrm{SD}<0.13 \mathrm{log}$ ). The coefficient of variation, ranged from 10 to $24 \%$ and from 27 to 36 $\%$ for within- and between-run assay, respectively.

Another factor to consider is the lower limit of detection of any quantification system. Since patients treated with modern combination therapy often present a very rapid decrease of viral load, which becomes undetectable by PCR (Mathe, 1999), there is a clear need for assays with very high sensitivity. With RT-nested PCR, detection of single RNA molecules is possible. Consequently, the competitor mixture should contain a very small amount of the least abundant competitor, but still enough copies to be reproducibly detected by the PCR. By solid-phase technology, with its possibility to concentrate target molecules, the limit of detection strictly depends on the volume of plasma available.

\subsection{Quantification of HIV-1 using multiple PCR competitors and bioluminescence detection (VII)}

With the aim to develop a quantitative, competitive and non gel-based PCR assay using the multiple competitor strategy, we evaluated a bioluminescent detection principle (VII). This detection system relies on the capability of an exonuclease-deficient DNA polymerase to distinguish between a match over a mismatch (at the $3^{\prime}$ termini) primer in an extension assay (Nyrén, 1997). The inorganic pyrophosphate (PPi) released as a result of successful extension is converted to ATP by ATP sulfurylase, and luciferase produces a proportional amount of visible light, which is detected by a luminometer .

In this study, we have chosen the HIV-1 polymerase gene as amplification target, since the primers located in the previously utilised 3 ' long terminal repeat (LTR) region failed to accurately quantify some isolates, probably due to polymorphic positions in the LTR region (VI). We also wanted to develop a system that minimizes the differences between the target and the competitor in respect to size, to rule out amplification bias. Amplification of the new competitor constructs results in PCR products of identical length as the HIV-1 target (138 bp) and differing at only four nucleotide positions. The principle of the competitive quantification method is outlined in Figure 13. 


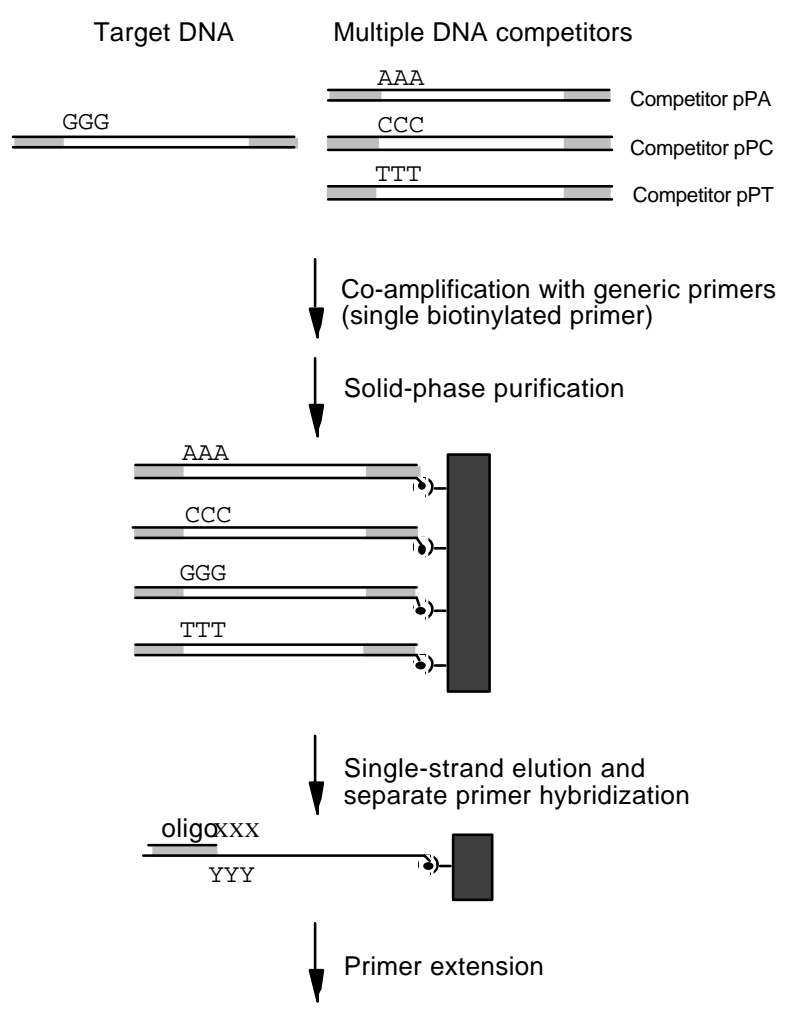

Bioluminometric detection

Figure 13. The basic concept of the bioluminometric technique for quantification of PCR products. The mixture of amplicons resulting from the single-tube PCR is captured onto the solid phase and made singlestranded, before divided into four aliquots and subjected to template-specific primer extension reactions. The inorganic pyrophosphate (PPi) released in the DNA polymerase-catalyzed reaction is monitored by coupled enzymatic reactions using ATP sulfurylase and luciferase. Light generated as a result of a successful extension is measured by a luminometer. The competitor signals are used to construct the internal calibration curve for estimation of the target copy number,

In this model system, the target (proviral HIV-1 DNA or a plasmid containing the cloned target) is co-amplified with the three plasmid DNA competitors using nested primers. The resulting biotinylated PCR fragments are immobilized onto streptavidincoated paramagnetic beads. After alkali treatment, immobilized single-stranded DNA is divided into four aliquots, which are each mixed with one of four specific oligonucleotides. These extension primers, differing over three nucleotides at the 3'-end, hybridize specifically to either the wild-type HIV amplicon or to one of the three 
competitor amplicons. The four resulting complexes are used as substrates in separate primer extension assays (Nyrén, 1997) to quantify the amount of each amplicon. The signals resulting from specific extension of each extension primer are directly correlated to the original amount of the target and competitors. The three competitors can thereby be used to create an internal calibration curve in order to allow estimation of the HIV target.

In this initial report, the dynamic range of the bioluminometric assay was expanded to be able to cover the copy number interval required for clinical analysis of HIV-1 viral load. This was achieved by use of two different competitor mixtures that together covered between 50 and 625000 copies. All combinations of extension primer and PCR amplicon were analyzed and all background signals were approximately $5 \%$ of the corresponding match signals. To further investigate the detection limit and the linearity of the bioluminometric primer extension assay, various amounts of one competitor amplicon were detected in a background consisting of a mixture of the other three amplicons. It was possible to reproducibly detect $0.025 \mu \mathrm{l}$ of a specific amplicon in a total of $5 \mu \mathrm{l}$ of PCR product, corresponding to a sensitivity of 1:200. In addition, a mixture of all four PCR amplicons in approximative relative amounts 1:5:25:125 was prepared, divided into four aliquots and analysed separately with all four extension primers. The obtained results demonstrate a linearity and conformity between duplicate samples (Fig. 14). In experiments including competitive PCR, different configurations of plasmids were used as template. Mix A (50, 250, 1250 and 6250 copies the four plasmids, respectively) and mix B (5 000, 25000,125000 and 625000 copies) were used to investigate whether the four plasmids were PCR amplified with the same efficiency. The results for the low-copy and high-copy mixtures show linearity in both intervals, thus indicating similar amplification efficiencies. To evaluate the quantification method on proviral HIV-1 DNA, a new competitor mixture containing 50, 560 and 6250 copies of the three competitors was established. This mixture was then used with 200 and 1000 copies of HIV-1 MN DNA (Myers G B, 1991), also estimated by separate enddilution experiments. A linear response was obtained making an estimation of the target copy number possible by using the internal calibration curves, which give an estimation of 203 and 1072 MN copies, respectively. The obtained results are in good agreement with the results obtained from end-point experiments. 
(A)

$$
\prod_{1} 1 \mathrm{pmol}
$$

pPT

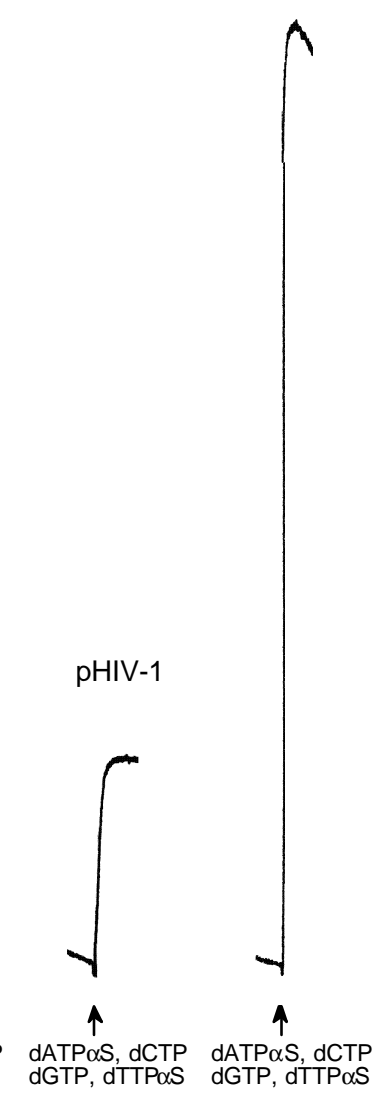

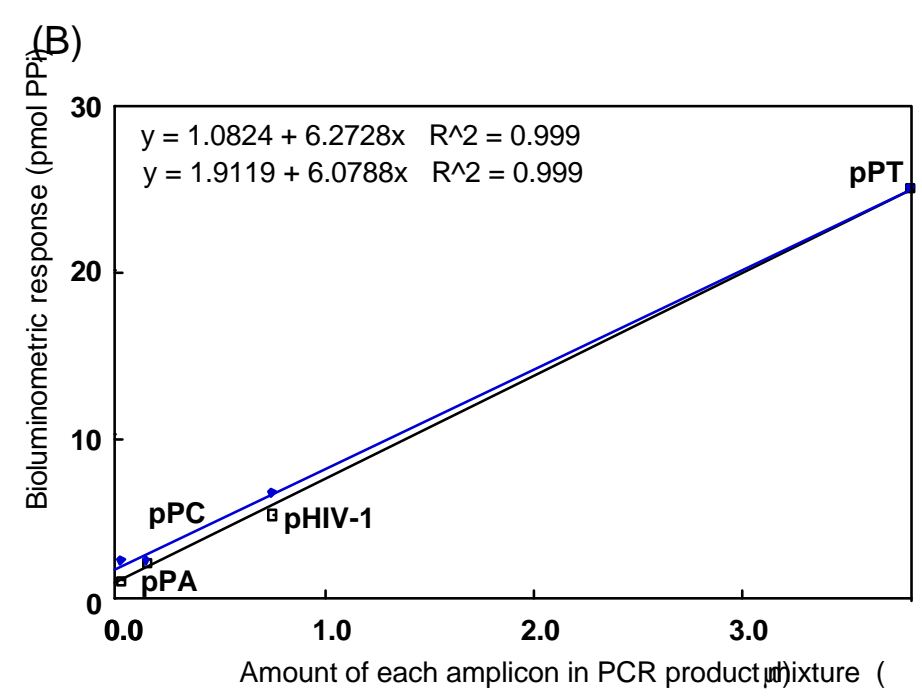

Figure 14. Luminometric traces (A) and calibration curve (B) from bioluminometric primer extension analysis of a mixture of PCR amplicons. The four plasmids were amplified separately and the PCR products were mixed in relative amounts 1:5:25:125. The mixture was then divided into four aliquots, each analysed with its respective extension primer. 


\section{NYGREN}

Alternatives to the mismatch extension principle also exist with the present competitors. It is possible to take advantage of the unique three-nucleotide homopolymeric sequences in the competitors and the target by designing a fully complementary primer (identical for target and competitors) adjacent to this region and perform one-basepair (dideoxynucleotides) or three-basepair (deoxynucleotides) extensions with individual nucleotides, resulting in four parallel extension reactions. Hereby we can theoretically from one and the same competitor obtain three different calibration signals. This could then be used to expand the dynamic interval of the bioluminometric assay by having three competitors with nine possible calibration signals. A fully automated instrument for pyrophosphate-based detection has recently been developed, enabling extension analysis of 96 DNA fragments simultaneously in less than five minutes. 


\section{ACKNOWLEDGEMENTS}

Jag vill av hela mitt hjärta tacka alla som genom åren gjort Institutionen för Bioteknologi vid KTH och framförallt DNA corner@ till en speciell plats på jorden; där det är en förmån att få vistas. När "forskningen" går trögt är det skönt att arbetskamraterna även är ens vänner.

Jag vill också speciellt tacka:

Min fantastiske handledare Joakim Lundeberg, den mest positiva och optimistiska människa jag har träffat. Tack för all hjälp och allt stöd genom åren, för tålamod och förståelse och för att du har stått ut med mig när jag emellanåt inte har stått ut med projekten...

Min professor Mathias Uhlén, för att jag fick börja arbeta hos dig och framförallt för att jag fick fortsätta... och för mina intressanta första projekt LacI-B-Galaktosidasproduktion, Immuno-PCR med streptavidin-SPA-produktion, Detach-a-Bead med antikroppskloning, PCR på fager mm, vilka tyvärr inte gav mig några publikationer, men dock en något skeptisk inställning att ha som motvikt till Joakims obotliga optimism.

\section{Jag vill naturligtvis tacka alla samarbetspartners, t ex:}

Elisabet Reizenstein och Lena Lindberg vid Smittskyddsinstitutet för era stora kunskaper om pertussis och för allt ert arbete med att läsa manuskript och odla stammar.

Jan Albert, AnnaLena Andesson och Maria Axelsson vid Smittskyddsinstitutet för bl a "äckligt" virusarbete.

Hela "Pyrogruppen" för generösa goda råd och särskilt Mostafa Ronaghi och Pål Nyrén.

Susanna Falklind som lyckades vända ett hopplöst exjobb till någonting användbart! Lotta Malmqvist som oroade sig mer för min stora, gravida mage än för sitt exjobb och blev så glad att se mig på jobbet varje morgon, då jag inte borde ha varit där.

Anders Hedrum för utmärkt handledande av ett (eller var det tre...) exjobb, som inte gick helt på räls... Och för att du fortfarande är en vän.

Bertil Pettersson, Kungen av Sekvensning.

Ni Dator-Hackers.

Alla de andra handledarna på Forskarskolan i Karlskoga 1993-1997, för roligt "sommarkollo" och trevliga sammankomster under övriga året. 


\section{NYGREN}

\section{Min familj;}

Åke och Ingrid Nygren för att ni så ofta och med kort varsel har låtit er motioneras av er lilla sondotter medan jag har brottats med flyttlådor och jobb.

Min älskade bror Tomas, som alltid ställer upp.

Min mamma och Per för omfattande barn-och hundpassning.

Min pappa och Ingrid för barnvakteri och pappa för mottot "Allt går, det omöjliga tar bara litet längre tid"-jag kan bara hålla med.

Min farmor Sinikka, som var så engagerad i barnbarnens utbildning och (en av de få) som säkert skulle ha läst min avhandling.

Mumlan i din hundhimmel för våra nio år tillsammans och för att du botade Per-Åkes hundrädsla, Bamse för att du nog är den på jorden som känner mig bäst, Fuffens för trivsamt snarkande och för att du har värmt mina fötter medan jag har suttit hemma och skrivit.

Älskade lilla Nelly, som lever efter mottot "Det är inte målet som är det viktiga, utan vägen dit", vilket antagligen gäller både när det är bråttom till dagmamman och när man disputerar.

Per-Åke, mitt allt! 


\section{REFERENCES}

Albert J, Wahlberg J, Lundeberg J, Cox S, Sandström E, Wahren B and Uhlén M. (1992) Persistence of azidothymidine-resistant human immunodeficiency virus type 1 RNA genotypes in posttreatment sera. J Virol 66:5627-5630.

Albert MJ. (1994) Vibrio cholerae O139 Bengal. J Clin Microbiol 32:2345-2349.

Albert MJ $a$, Islam D, Nahar S, Qadri F, Falklind S and Weintraub A. (1997) Rapid detection of Vibrio cholerae O139 Bengal from stool specimens by PCR. J Clin Microbiol 35:1633-1635.

Albert MJ $b$, Bhuiyan NA, Talukder KA, Faruque AS, Nahar S, Faruque SM, Ansaruzzaman M and Rahman M. (1997) Phenotypic and genotypic changes in Vibrio cholerae O139 Bengal. J Clin Microbiol 35:2588-2592.

Amano K, Fukushi K and Watanabe M. (1990) Biochemical and immunological comparison of lipopolysaccharides from Bordetella species. J Gen Microbiol 136:481-487.

Apple RJ, Becker TM, Wheeler CM and Erlich HA. (1995) Comparison of human leukocyte antigen DRDQ disease associations found with cervical dysplasia and invasive cervical carcinoma. $\boldsymbol{J}$ Natl Cancer Inst 87:427-436.

Arnold LJ, Jr., Hammond PW, Wiese WA and Nelson NC. (1989) Assay formats involving acridiniumester-labeled DNA probes. Clin Chem 35:1588-1594.

Arya SC. (1997) PCR-based detection of Vibrio cholerae O139 Bengal with sequences encoding glycosyltransferases. J Clin Microbiol 35:3364.

Asai S, Noda M, Yamamura M, Hozumi Y, Takase I, Nitta H, Sato M and Namikawa I. (1993) Comparative study of the cellular fatty acids of methicillin-resistant and -susceptible Staphylococcus aureus. APMIS. 101:753-761.

Bains W and Smith GC. (1988) A novel method for nucleic acid sequence determination. J Theor Biol 135:303-307.

Ballard AL, Cane PA and Pillay D. (1998) HIV drug resistance: genotypic assays and their possible applications. Sex Transm Infect 74:243-248.

Bannerman TL, Hancock GA, Tenover FC and Miller JM. (1995) Pulsed-field gel electrophoresis as a replacement for bacteriophage typing of Staphylococcus aureus. J Clin Microbiol 33:551-555.

Barany F. (1991) Genetic disease detection and DNA amplification using cloned thermostable ligase. Proc Natl Acad Sci U S A 88:189-193.

Barnes WM. (1994) PCR amplification of up to 35-kb DNA with high fidelity and high yield from lambda bacteriophage templates. Proc Natl Acad Sci U S A 91:2216-2220.

Barré-Sinoussi F, Chermann JC, Rey F, Nugeyre MT, Chamaret S, Gruest J, Dauguet C, Axler-Blin C, Vezinet-Brun F, Rouzioux C, Rozenbaum W and Montagnier L. (1983) Isolation of a Tlymphotropic retrovirus from a patient at risk for acquired immune deficiency syndrome (AIDS). Science 220:868-871.

Beardsley T. (1992) Paradise lost? Microbes mount a comeback as drug resistance spreads. Sci Am 267:1820. 


\section{NYGREN}

Becker-André M and Hahlbrock K. (1989) Absolute mRNA quantification using the polymerase chain reaction (PCR). A novel approach by a PCR aided transcript titration assay (PATTY). Nucleic Acids Res 17:9437-9446.

Bej AK, Mahbubani MH, Dicesare JL and Atlas RM. (1991) Polymerase chain reaction-gene probe detection of microorganisms by using filter-concentrated samples. Appl Environ Microbiol 57:3529-3534.

Birch DE. (1996) Simplified hot start PCR. Nature 381:445-446.

Blanc DS, Lugeon C, Wenger A, Siegrist HH and Francioli P. (1994) Quantitative antibiogram typing using inhibition zone diameters compared with ribotyping for epidemiological typing of methicillinresistant Staphylococcus aureus. J Clin Microbiol 32:2505-2509.

Braun A, Little DP and Koster H. (1997) Detecting CFTR gene mutations by using primer oligo base extension and mass spectrometry. Clin Chem 43:1151-1158.

Brechot C. (1997) Hepatitis C virus 1b, cirrhosis, and hepatocellular carcinoma. Hepatology 25:772-774.

Brinchmann JE, Albert $\mathbf{J}$ and Vartdal F. (1991) Few infected CD4+ T cells but a high proportion of replication- competent provirus copies in asymptomatic human immunodeficiency virus type 1 infection. J Virol 65:2019-2023.

Brown A, Akinsanya AA, Barker SJ, Brophy M, Dobb AK, Doyle SM, Hudson IR, Minter SJ, Wraith MJ and Oultram JD. (1999) Automated system for capture and detection of nucleic acids. Biotechniques 27:176-180.

Brownie J, Shawcross S, Theaker J, Whitcombe D, Ferrie R, Newton C and Little S. (1997) The elimination of primer-dimer accumulation in PCR. Nucleic Acids Res 25:3235-3241.

Buck GE. (1996) Detection of Bordetella pertussis by rapid-cycle PCR and colorimetric microwell hybridization. J Clin Microbiol 34:1355-1358.

Bugawan TL, Horn GT, Long CM, Mickelson E, Hansen JA, Ferrara GB, Angelini G and Erlich HA. (1988) Analysis of HLA-DP allelic sequence polymorphism using the in vitro enzymatic DNA amplification of DP-alpha and DP-beta loci. J Immunol 141:4024-4030.

Burns MA, Mastrangelo CH, Sammarco TS, Man FP, Webster JR, Johnsons BN, Foerster B, Jones D, Fields Y, Kaiser AR and Burke DT. (1996) Microfabricated structures for integrated DNA analysis. Proc Natl Acad Sci U S A 93:5556-5561.

Carothers AM, Urlaub G, Mucha J, Grunberger D and Chasin LA. (1989) Point mutation analysis in a mammalian gene: rapid preparation of total RNA, PCR amplification of cDNA, and Taq sequencing by a novel method. Biotechniques 7:494-496, 498-499.

Castro, A and Shera EB. (1995) Single-molecule electrophoresis. Anal Chem 67:3181-3186.

Chamberlain JS, Gibbs RA, Ranier JE, Nguyen PN and Caskey CT. (1988) Deletion screening of the Duchenne muscular dystrophy locus via multiplex DNA amplification. Nucleic Acids Res 16:11141-11156.

Chang Y, Cesarman E, Pessin MS, Lee F, Culpepper J, Knowles DM and Moore PS. (1994) Identification of herpesvirus-like DNA sequences in AIDS-associated Kaposi's sarcoma. Science 266:1865-1869.

Chen X, Livak KJ and Kwok PY. (1998) A homogeneous, ligase-mediated DNA diagnostic test. Genome Res 8:549-556. 
Chen X, Zehnbauer B, Gnirke A and Kwok PY. (1997) Fluorescence energy transfer detection as a homogeneous DNA diagnostic method. Proc Natl Acad Sci U S A 94:10756-10761.

Cheng J, Shoffner MA, Hvichia GE, Kricka LJ and Wilding P. (1996) Chip PCR. II. Investigation of different PCR amplification systems in microbabricated silicon-glass chips. Nucleic Acids Res 24:380-385.

Chou Q, Russell M, Birch DE, Raymond J and Bloch W. (1992) Prevention of pre-PCR mis-priming and primer dimerization improves low- copy-number amplifications. Nucleic Acids Res 20:1717-1723.

Chun TW, L. Carruth, D. Finzi, X. Chen, J. A. DiGuiseppe, H. Taylor, M. Hermankova, K. Chadwick, J. Margolick, T. C, Quinn, Y. H. Kuo, R. Brookmeyer, M. A. Zeiger, P. Barditch-Crovo, and R. F. Siliciano. (1997) Quantification of latent tissue reservoirs and total body viral load in HIV-1 infection. Nature 837:183-188.

Clarke JR and McClure MO. (1999) HIV-1 viral load testing. J Infect 38:141-146.

Colgrove R and Japour A. (1999) A combinatorial ledge: reverse transcriptase fidelity, total body viral burden, and the implications of multiple-drug HIV therapy for the evolution of antiviral resistance. Antiviral Res 41:45-56.

Compton J. (1991) Nucleic acid sequence-based amplification. Nature 350:91-92.

Comstock LE, Johnson JA, Michalski JM, Morris JG, Jr. and Kaper JB. (1996) Cloning and sequence of a region encoding a surface polysaccharide of Vibrio cholerae $\mathrm{O} 139$ and characterization of the insertion site in the chromosome of Vibrio cholerae O1. Mol Microbiol 19:815-826.

Control CfD. (1982) Unexplained immunodeficiency and opportunistic infections in infants-New York, New Jersey, California. Morbid Mortal Weekly Rep 31:507-514.

Deggerdal A and Larsen F. (1997) Rapid isolation of PCR-ready DNA from blood, bone marrow and cultured cells, based on paramagnetic beads. Biotechniques 22:554-557.

DiCesare J, Grossman B, Katz E, Picozza E, Ragusa R and Woudenberg T. (1993) A high-sensitivity electrochemiluminescence-based detection system for automated PCR product quantitation. Biotechniques 15:152-157.

Dijkshoorn L, Aucken H, Gerner-Smidt P, Janssen P, Kaufmann ME, Garaizar J, Ursing J and Pitt TL. (1996) Comparison of outbreak and nonoutbreak Acinetobacter baumannii strains by genotypic and phenotypic methods. J Clin Microbiol 34:1519-1525.

Douglas E, Coote JG, Parton R and McPheat W. (1993) Identification of Bordetella pertussis in nasopharyngeal swabs by PCR amplification of a region of the adenylate cyclase gene. $\boldsymbol{J}$ Med Microbiol 38:140-144.

Drmanac S, Kita D, Labat I, Hauser B, Schmidt C, Burczak JD and Drmanac R. (1998) Accurate sequencing by hybridization for DNA diagnostics and individual genomics. Nat Biotechnol 16:5458 .

Dubiley S, Kirillov E, Lysov Y and Mirzabekov A. (1997) Fractionation, phosphorylation and ligation on oligonucleotide microchips to enhance sequencing by hybridization. Nucleic Acids Res 25:22592265 .

Dumler JS, Asanovich KM, Bakken JS, Richter P, Kimsey R and Madigan JE. (1995) Serologic crossreactions among Ehrlichia equi, Ehrlichia phagocytophila, and human granulocytic Ehrlichia. $\boldsymbol{J}$ Clin Microbiol 33:1098-1103. 


\section{NYGREN}

Eigen M and Rigler R. (1994) Sorting single molecules: application to diagnostics and evolutionary biotechnology. Proc Natl Acad Sci U S A 91:5740-5747.

el-Farrash MA, Kuroda MJ, Kitazaki T, Masuda T, Kato K, Hatanaka M and Harada S. (1994) Generation and characterization of a human immunodeficiency virus type 1 (HIV-1) mutant resistant to an HIV1 protease inhibitor. $\boldsymbol{J}$ Virol 68:233-239.

el-Osta A, Kantharidis P and Zalcberg J. (1999) Absolute quantitation of MDR1 transcripts using heterologous DNA standards-validation of the competitive RT-PCR (CRT-PCR) approach. Biotechniques 26:1114-1116, 1118-1120, 1122

Elghanian R, Storhoff JJ, Mucic RC, Letsinger RL and Mirkin CA. (1997) Selective colorimetric detection of polynucleotides based on the distance-dependent optical properties of gold nanoparticles. Science 277:1078-1081.

Faruque AS, Fuchs GJ and Albert MJ. (1996) Changing epidemiology of cholera due to Vibrio cholerae O1 and O139 Bengal in Dhaka, Bangladesh. Epidemiol Infect 116:275-278.

Faruque SM, Ahmed KM, Abdul Alim AR, Qadri F, Siddique AK and Albert MJ. (1997) Emergence of a new clone of toxigenic Vibrio cholerae O1 biotype El Tor displacing V. cholerae O139 Bengal in Bangladesh. J Clin Microbiol 35:624-630.

Faruque SM, Siddique AK, Saha MN, Asadulghani, Rahman MM, Zaman K, Albert MJ, Sack DA and Sack RB. (1999) Molecular characterization of a new ribotype of Vibrio cholerae O139 Bengal associated with an outbreak of cholera in Bangladesh. J Clin Microbiol 37:1313-1318.

Fasco MJ, Treanor CP, Spivack S, Figge HL and Kaminsky LS. (1995) Quantitative RNA-polymerase chain reaction-DNA analysis by capillary electrophoresis and laser-induced fluorescence. Anal Biochem 224:140-147.

Feldmann H, Sanchez A, Morzunov S, Spiropoulou CF, Rollin PE, Ksiazek TG, Peters CJ and Nichol ST. (1993) Utilization of autopsy RNA for the synthesis of the nucleocapsid antigen of a newly recognized virus associated with hantavirus pulmonary syndrome. Virus Res 30:351-367.

Fiorenza MT and Mangia F. (1998) Quantitative RT-PCR amplification of RNA in single mouse oocytes and preimplantation embryos. Biotechniques 24:618-623.

Fire A and Xu SQ. (1995) Rolling replication of short DNA circles. Proc Natl Acad Sci U S A 92:46414645 .

Fredericks DN and Relman DA. (1996) Sequence-based identification of microbial pathogens: a reconsideration of Koch's postulates. Clin Microbiol Rev 9:18-33.

Freeman WM, Walker SJ and Vrana KE. (1999) Quantitative RT-PCR: pitfalls and potential. Biotechniques 26:112-122, 124-115.

Gibson NJ $a$, Newton CR and Little S. (1997) A colorimetric assay for phosphate to measure amplicon accumulation in polymerase chain reaction. Anal Biochem 254:18-22.

Gibson NJ $b$, Gillard HL, Whitcombe D, Ferrie RM, Newton CR and Little S. (1997) A homogeneous method for genotyping with fluorescence polarization. Clin Chem 43:1336-1341.

Gibson UE, Heid CA and Williams PM. (1996) A novel method for real time quantitative RT-PCR. Genome Res 6:995-1001. 
Glare EM, Paton JC, Premier RR, Lawrence AJ and Nisbet IT. (1990) Analysis of a repetitive DNA sequence from Bordetella pertussis and its application to the diagnosis of pertussis using the polymerase chain reaction. J Clin Microbiol 28:1982-1987.

Graham WES, A M T Linacre, C H Munro, N D Watsson and P C White. (1997) Selective detection of deoxyribonucleic acid at ultralow concentrations by SERRS. Anal Chem 69:4703-4707.

Greensfield L and White T J, in D H Persing, T F Smith., F C Tenover and T J White (Ed.), Diagnostic Molecular Microbiology: Principles and Applications, ASM Press, Washington, D.C 1993, p. 122137.

Gruner E, Bernasconi E, Galeazzi RL, Buhl D, Heinzle R and Nadal D. (1994) Brucellosis: an occupational hazard for medical laboratory personnel. Report of five cases. Infection 22:33-36.

Guatelli JC, Whitfield KM, Kwoh DY, Barringer KJ, Richman DD and Gingeras TR. (1990) Isothermal, in vitro amplification of nucleic acids by a multienzyme reaction modeled after retroviral replication [published erratum appears in Proc Natl Acad Sci U S A 1990 Oct;87(19):7797]. Proc Natl Acad Sci U S A 87:1874-1878.

Halford WP. (1999) The essential prerequisites for quantitative RT-PCR. Nat Biotechnol 17:835.

Hayward-Lester A, Oefner PJ, Sabatini S and Doris PA. (1995) Accurate and absolute quantitative measurement of gene expression by single-tube RT-PCR and HPLC. Genome Res 5:494-499.

He Q, Mertsola J, Soini H, Skurnik M, Ruuskanen O and Viljanen MK. (1993) Comparison of polymerase chain reaction with culture and enzyme immunoassay for diagnosis of pertussis. J Clin Microbiol 31:642-645.

Heid CA, Stevens J, Livak KJ and Williams PM. (1996) Real time quantitative PCR. Genome Res 6:986994.

Higgins GS, Little DP and Koster H. (1997) Competitive oligonucleotide single-base extension combined with mass spectrometric detection for mutation screening. Biotechniques 23:710-714.

Higuchi R, Dollinger G, Walsh PS and Griffith R. (1992) Simultaneous amplification and detection of specific DNA sequences. Biotechnology 10:413-417.

Hill AV, Elvin J, Willis AC, Aidoo M, Allsopp CE, Gotch FM, Gao XM, Takiguchi M, Greenwood BM, Townsend AR and et al. (1992) Molecular analysis of the association of HLA-B53 and resistance to severe malaria. Nature 360:434-439.

Hillenkamp F, Karas M, Beavis RC and Chait BT. (1991) Matrix-assisted laser desorption/ionization mass spectrometry of biopolymers. Anal Chem 63:1193A-1203A.

Hodinka RL. (1998) The clinical utility of viral quantitation using molecular methods. Clin Diagn Virol 10:25-47.

Holland PM, Abramson RD, Watson R and Gelfand DH. (1991) Detection of specific polymerase chain reaction product by utilizing the 5'->3' exonuclease activity of Thermus aquaticus DNA polymerase.

Proc Natl Acad Sci U S A 88:7276-7280.

Hoshino K, Yamasaki S, Mukhopadhyay AK, Chakraborty S, Basu A, Bhattacharya SK, Nair GB, Shimada T and Takeda Y. (1998) Development and evaluation of a multiplex PCR assay for rapid detection of toxigenic Vibrio cholerae O1 and O139. FEMS Immunol Med Microbiol 20:201-207.

Houard S, Hackel C, Herzog A and Bollen A. (1989) Specific identification of Bordetella pertussis by the polymerase chain reaction. Res Microbiol 140:477-487. 


\section{NYGREN}

Hultman T, Ståhl S, Hornes E and Uhlén M. (1989) Direct solid phase sequencing of genomic and plasmid DNA using magnetic beads as solid support. Nucleic Acids Res 17:4937-4946.

Ibrahim MS, Esposito JJ, Jahrling PB and Lofts RS. (1997) The potential of 5 ' nuclease PCR for detecting a single-base polymorphism in Orthopoxvirus. Mol Cell Probes 11:143-147.

Ibrahim MS, Lofts RS, Jahrling PB, Henchal EA, Weedn VW, Northrup MA and Belgrader P. (1998) Realtime microchip PCR for detecting single-base differences in viral and human DNA. Anal Chem 70:2013-2017.

Ichiyama S, Iinuma Y, Tawada Y, Yamori S, Hasegawa Y, Shimokata K and Nakashima N. (1996) Evaluation of Gen-Probe Amplified Mycobacterium Tuberculosis Direct Test and Roche PCRmicrowell plate hybridization method (AMPLICOR MYCOBACTERIUM) for direct detection of mycobacteria. J Clin Microbiol 34:130-133.

Innis MA, Myambo KB, Gelfand DH and Brow MA. (1988) DNA sequencing with Thermus aquaticus DNA polymerase and direct sequencing of polymerase chain reaction-amplified DNA. Proc Natl Acad Sci U S A 85:9436-9440.

Jacobson KB, Arlinghaus HF, Buchanan MV, Chen CH, Glish GL, Hettich RL and McLuckey SA. (1991) Applications of mass spectrometry to DNA sequencing. Genet Anal Tech Appl 8:223-229.

Johnson JA, Salles CA, Panigrahi P, Albert MJ, Wright AC, Johnson RJ and Morris JG, Jr. (1994) Vibrio cholerae $\mathrm{O} 139$ synonym bengal is closely related to Vibrio cholerae El Tor but has important differences. Infect Immun 62:2108-2110.

Johnson WM, Tyler SD, Ewan EP, Ashton FE, Pollard DR and Rozee KR. (1991) Detection of genes for enterotoxins, exfoliative toxins, and toxic shock syndrome toxin 1 in Staphylococcus aureus by the polymerase chain reaction. J Clin Microbiol 29:426-430.

Kai E, Sawata S, Ikebukuro K, Iida T, Honda T and Karube I. (1999) Detection of PCR products in solution using surface plasmon resonance. Anal Chem 71:796-800.

Kalinina O, Lebedeva I, Brown J and Silver J. (1997) Nanoliter scale PCR with TaqMan detection. Nucleic Acids Res 25:1999-2004.

Katzko G, Hofmeister M and Church D. (1996) Extended incubation of culture plates improves recovery of Bordetella spp. J Clin Microbiol 34:1563-1564.

Kaufhold A, Podbielski A, Baumgarten G, Blokpoel M, Top J and Schouls L. (1994) Rapid typing of group A streptococci by the use of DNA amplification and non-radioactive allele-specific oligonucleotide probes. FEMS Microbiol Lett 119:19-25.

Keene WE, Sazie E, Kok J, Rice DH, Hancock DD, Balan VK, Zhao T and Doyle MP. (1997) An outbreak of Escherichia coli O157:H7 infections traced to jerky made from deer meat. JAMA 277:12291231 .

Kellogg DE, Rybalkin I, Chen S, Mukhamedova N, Vlasik T, Siebert PD and Chenchik A. (1994) TaqStart Antibody: "hot start" PCR facilitated by a neutralizing monoclonal antibody directed against Taq DNA polymerase. Biotechniques 16:1134-1137.

Kemp DJ, Smith DB, Foote SJ, Samaras N and Peterson MG. (1989) Colorimetric detection of specific DNA segments amplified by polymerase chain reactions. Proc Natl Acad Sci U S A 86:2423-2427.

Khattak MN and Matthews RC. (1993) Genetic relatedness of Bordetella species as determined by macrorestriction digests resolved by pulsed-field gel electrophoresis. Int J Syst Bacteriol 43:659664. 
Kilian M, Sorensen I and Frederiksen W. (1979) Biochemical characteristics of 130 recent isolates from Haemophilus influenzae meningitis. J Clin Microbiol 9:409-412.

Klausner PDFaA. (1988) Amplifying DNA probe signals: a "Christmas tree" approach. Bio/Technology 6:1165-1168.

Koch R, in Clark, D. H. (Ed.), Source book of medical history, Dover Publications, Inc., New York 1942, p. 392-406.

Kohsaka H, Taniguchi A, Richman DD and Carson DA. (1993) Microtiter format gene quantification by covalent capture of competitive PCR products: application to HIV-1 detection. Nucleic Acids Res 21:3469-3472.

Kopp MU, Mello AJ and Manz A. (1998) Chemical amplification: continuous-flow PCR on a chip. Science 280:1046-1048.

Kostrikis LG, Tyagi S, Mhlanga MM, Ho DD and Kramer FR. (1998) Spectral genotyping of human alleles. Science 279:1228-1229.

Kramer FR and Lizardi PM. (1989) Replicatable RNA reporters. Nature 339:401-402.

Kwoh DY, Davis GR, Whitfield KM, Chappelle HL, DiMichele LJ and Gingeras TR. (1989) Transcriptionbased amplification system and detection of amplified human immunodeficiency virus type 1 with a bead-based sandwich hybridization format. Proc Natl Acad Sci U S A 86:1173-1177.

Labenz J and Borsch G. (1994) Evidence for the essential role of Helicobacter pylori in gastric ulcer disease. Gut 35:19-22.

Lahijani R, Duhon M, Lusby E, Betita H and Marquet M. (1998) Quantitation of host cell DNA contaminate in pharmaceutical-grade plasmid DNA using competitive polymerase chain reaction and enzyme- linked immunosorbent assay. Hum Gene Ther 9:1173-1180.

Landegren U, Kaiser R, Sanders J and Hood L. (1988) A ligase-mediated gene detection technique. Science 241:1077-1080.

Larder BA and Kemp SD. (1989) Multiple mutations in HIV-1 reverse transcriptase confer high-level resistance to zidovudine (AZT). Science 246:1155-1158.

Lesmana M, Albert MJ, Subekti D, Richie E, Tjaniadi P, Walz SE and Lebron CI. (1996) Simple differentiation of Vibrio cholerae $\mathrm{O} 139$ from V. cholerae $\mathrm{O} 1$ and non-O1, non-O139 by modified CAMP test. J Clin Microbiol 34:1038-1040.

Li Z, Jansen DL, Finn TM, Halperin SA, Kasina A, O'Connor SP, Aoyama T, Manclark CR and Brennan MJ. (1994) Identification of Bordetella pertussis infection by shared-primer PCR. J Clin Microbiol 32:783-789.

Lichtinghagen R, Diedrich-Glaubitz R and von Horsten B. (1994) Identification of Bordetella pertussis in nasopharyngeal swabs using the polymerase chain reaction: evaluation of detection methods. Eur $\boldsymbol{J}$ Clin Chem Clin Biochem 32:161-167.

Lin HJ, Pedneault L and Hollinger FB. (1998) Intra-assay performance characteristics of five assays for quantification of human immunodeficiency virus type 1 RNA in plasma. $\boldsymbol{J}$ Clin Microbiol 36:835839.

Little DP, Thannhauser TW and McLafferty FW. (1995) Verification of 50- to 100-mer DNA and RNA sequences with high- resolution mass spectrometry. Proc Natl Acad Sci U S A 92:2318-2322. 


\section{NYGREN}

Livak KJ, Flood SJ, Marmaro J, Giusti W and Deetz K. (1995) Oligonucleotides with fluorescent dyes at opposite ends provide a quenched probe system useful for detecting PCR product and nucleic acid hybridization. PCR Methods Appl 4:357-362.

Lizardi PM, Huang X, Zhu Z, Bray-Ward P, Thomas DC and Ward DC. (1998) Mutation detection and single-molecule counting using isothermal rolling-circle amplification. Nat Genet 19:225-232.

Loitsch SM, Kippenberger S, Dauletbaev N, Wagner TO and Bargon J. (1999) Reverse transcriptioncompetitive multiplex PCR improves quantification of mRNA in clinical samples--application to the low abundance CFTR mRNA. Clin Chem 45:619-624.

Lomeli H, Tyagi S, Pritchard CG, Lizardi PM and Kramer FR. (1989) Quantitative assays based on the use of replicatable hybridization probes. Clin Chem 35:1826-1831.

Luk JM, Kongmuang U, Reeves PR and Lindberg AA. (1993) Selective amplification of abequose and paratose synthase genes ( $\mathrm{rfb}$ ) by polymerase chain reaction for identification of Salmonella major serogroups (A, B, C2, and D). J Clin Microbiol 31:2118-2123.

Lundberg KS, Shoemaker DD, Adams MW, Short JM, Sorge JA and Mathur EJ. (1991) High-fidelity amplification using a thermostable DNA polymerase isolated from Pyrococcus furiosus. Gene 108:1-6.

Lundeberg J, Wahlberg J and Uhlén M. (1991) Rapid colorimetric quantification of PCR-amplified DNA. Biotechniques 10:68-75.

Lyamichev V, Mast AL, Hall JG, Prudent JR, Kaiser MW, Takova T, Kwiatkowski RW, Sander TJ, de Arruda M, Arco DA, Neri BP and Brow MA. (1999) Polymorphism identification and quantitative detection of genomic DNA by invasive cleavage of oligonucleotide probes. Nat Biotechnol 17:292296.

Manchester KL. (1995) Louis Pasteur (1822-1895)--chance and the prepared mind. Trends Biotechnol 13:511-515.

Mantero G, Zonaro A, Albertini A, Bertolo P and Primi D. (1991) DNA enzyme immunoassay: general method for detecting products of polymerase chain reaction. Clin Chem 37:422-429.

Marwick C. (1995) Acellular pertussis vaccine hailed for infants. JAMA 274:446-447.

Mathe G. (1999) Combinations of four virostatics applied in rotational sequences induce an exponential VL regression curve, the first part of which is rapidly decreasing to a PCR-undetectable level, while the last part is insensitive to the model. Indications for virostatic and immunotherapeutic reinforcements?. Biomed Pharmacother 53:57-62.

Maxam AM and Gilbert W. (1977) A new method for sequencing DNA. Proc Natl Acad Sci U S A 74:560564.

Mayer LW. (1988) Use of plasmid profiles in epidemiologic surveillance of disease outbreaks and in tracing the transmission of antibiotic resistance. Clin Microbiol Rev 1:228-243.

Meade BD and Bollen A. (1994) Recommendations for use of the polymerase chain reaction in the diagnosis of Bordetella pertussis infections. J Med Microbiol 41:51-55.

Mellors JW, Rinaldo CR, Jr., Gupta P, White RM, Todd JA and Kingsley LA. (1996) Prognosis in HIV-1 infection predicted by the quantity of virus in plasma [see comments] [published erratum appears in Science 1997 Jan 3;275(5296):14]. Science 272:1167-1170. 
Michael NL. (1999) Host genetic influences on HIV-1 pathogenesis. Curr Opin Immunol 11:466-474.

Mink CM, O'Brien CH, Wassilak S, Deforest A and Meade BD. (1994) Isotype and antigen specificity of pertussis agglutinins following whole-cell pertussis vaccination and infection with Bordetella pertussis. Infect Immun 62:1118-1120.

Mitra R, Basu A, Dutta D, Nair GB and Takeda Y. (1996) Resurgence of Vibrio cholerae O139 Bengal with altered antibiogram in Calcutta, India. Lancet 348:1181.

Mitra RD and Church GM. (1999) In situ localized amplification and contact replication of many individual DNA molecules. Nucleic Acids Res 27:e34.

Mooi FR and Bik EM. (1997) The evolution of epidemic Vibrio cholerae strains. Trends Microbiol 5:161165.

Morandi PA, G. A. Schockmel, S. Yerli, P. Burgisser, P. Erb, L. Matter, R. Sitavanc, and L. Perrin. (1998) Detection of human immunodeficiency virus type 1 (HIV-1) RNA in pools of sera negative for antibodies to HIV-1 and HIV-2. J Clin Microbiol 36:1534-1538.

Morrison C and Gannon F. (1994) The impact of the PCR plateau phase on quantitative PCR. Biochim Biophys Acta 1219:493-498.

Müller FM, Hoppe JE and Wirsing von Konig CH. (1997) Laboratory diagnosis of pertussis: state of the art in 1997. J Clin Microbiol 35:2435-2443.

Mullis KB. (1991) The polymerase chain reaction in an anemic mode: how to avoid cold oligodeoxyribonuclear fusion. PCR Methods Appl 1:1-4.

Mullis KB and Faloona FA. (1987) Specific synthesis of DNA in vitro via a polymerase-catalyzed chain reaction. Methods Enzymol 155:335-350.

Musser JM, Hewlett EL, Peppler MS and Selander RK. (1986) Genetic diversity and relationships in populations of Bordetella spp. J Bacteriol 166:230-237.

Myers G, B. Korber, J. Berkofsky, F. Smith, and G. N. Pevlakis, , Los Alamos National Laboratory, Los Alamos, N. Mex. 1991.

Myers TW and Gelfand DH. (1991) Reverse transcription and DNA amplification by a Thermus thermophilus DNA polymerase. Biochemistry 30:7661-7666.

Nahmias AJ, Weiss J, Yao X, Lee F, Kodsi R, Schanfield M, Matthews T, Bolognesi D, Durack D, Motulsky A and et al. (1986) Evidence for human infection with an HTLV III/LAV-like virus in Central Africa, 1959. Lancet 1:1279-1280.

Nair GB, Bag PK, Shimada T, Ramamurthy T, Takeda T, Yamamoto S, Kurazono H and Takeda Y. (1995) Evaluation of DNA probes for specific detection of Vibrio cholerae O139 Bengal. J Clin Microbiol 33:2186-2187.

Nazarenko IA, Bhatnagar SK and Hohman RJ. (1997) A closed tube format for amplification and detection of DNA based on energy transfer. Nucleic Acids Res 25:2516-2521.

Nelson NC. (1998) Rapid detection of genetic mutations using the chemiluminescent hybridization protection assay (HPA): overview and comparison with other methods. Crit Rev Clin Lab Sci $35: 369-414$.

Nelson NC, Hammond PW, Matsuda E, Goud AA and Becker MM. (1996) Detection of all single-base mismatches in solution by chemiluminescence. Nucleic Acids Res 24:4998-5003. 


\section{NYGREN}

Newton CR, Graham A, Heptinstall LE, Powell SJ, Summers C, Kalsheker N, Smith JC and Markham AF. (1989) Analysis of any point mutation in DNA. The amplification refractory mutation system (ARMS). Nucleic Acids Res 17:2503-2516.

Ng LK, Carballo M and Dillon JA. (1995) Differentiation of Neisseria gonorrhoeae isolates requiring proline, citrulline, and uracil by plasmid content, serotyping, and pulsed-field gel electrophoresis. $\boldsymbol{J}$ Clin Microbiol 33:1039-1041.

Nielsen PE, Egholm M, Berg RH and Buchardt O. (1991) Sequence-selective recognition of DNA by strand displacement with a thymine-substituted polyamide. Science 254:1497-1500.

Nilsson J, Bosnes M, Larsen F, Nygren PÅ, Uhlén M and Lundeberg J. (1997) Heat-mediated activation of affinity-immobilized Taq DNA polymerase. Biotechniques 22:744-751.

Nilsson P, Persson B, Larsson A, Uhlén M and Nygren PÅ. (1997) Detection of mutations in PCR products from clinical samples by surface plasmon resonance. J Mol Recognit 10:7-17.

Northrup MA, Benett B, Hadley D, Landre P, Lehew S, Richards J and Stratton P. (1998) A miniature analytical instrument for nucleic acids based on micromachined silicon reaction chambers. Anal Chem 70:918-922.

Nuovo GJ, Gallery F, Hom R, MacConnell P and Bloch W. (1993) Importance of different variables for enhancing in situ detection of PCR-amplified DNA. PCR Methods Appl 2:305-312.

Nyrén P, Karamohamed S and Ronaghi M. (1997) Detection of single-base changes using a bioluminometric primer extension assay. Anal Biochem 244:367-373.

O'Meara D, Yun Z, Sönnerborg A and Lundeberg J. (1998) Cooperative oligonucleotides mediating direct capture of hepatitis C virus RNA from serum. J Clin Microbiol 36:2454-2459.

Oefner PJ, Huber CG, Puchhammer-Stockl E, Umlauft F, Grunewald K, Bonn GK and Kunz C. (1994) High-performance liquid chromatography for routine analysis of hepatitis $\mathrm{C}$ virus cDNA/PCR products. Biotechniques 16:898-899, 902-898.

Olcén P, Bäckman A, Johansson B, Esbjørner E, Tornqvist E, Bygraves J and McPheat WL. (1992) Amplification of DNA by the polymerase chain reaction for the efficient diagnosis of pertussis. Scand J Infect Dis 24:339-345.

Olsvik Ø, Popovic T, Skjerve E, Cudjoe KS, Hornes E, Ugelstad J and Uhlén M. (1994) Magnetic separation techniques in diagnostic microbiology. Clin Microbiol Rev 7:43-54.

Onorato IM and Wassilak SG. (1987) Laboratory diagnosis of pertussis: the state of the art. Pediatr Infect Dis J 6:145-151.

Pannetier C, Delassus S, Darche S, Saucier C and Kourilsky P. (1993) Quantitative titration of nucleic acids by enzymatic amplification reactions run to saturation. Nucleic Acids Res 21:577-583.

Pastinen T, Kurg A, Metspalu A, Peltonen L and Syvänen AC. (1997) Minisequencing: a specific tool for DNA analysis and diagnostics on oligonucleotide arrays. Genome Res 7:606-614.

Perelson AS, Neumann AU, Markowitz M, Leonard JM and Ho DD. (1996) HIV-1 dynamics in vivo: virion clearance rate, infected cell life-span, and viral generation time. Science 271:1582-1586.

Persing DH, in D H Persing, T F Smith., F C Tenover and T J White (Ed.), Diagnostic Molecular Microbiology: Principles and Applications, ASM Press, Washington, D.C. 1993, p. 51-87. 
Piatak M, Jr., Luk KC, Williams B and Lifson JD. (1993) Quantitative competitive polymerase chain reaction for accurate quantitation of HIV DNA and RNA species. Biotechniques 14:70-81.

Pitt TL and Gaston MA. (1995) Bacteriophage typing. Methods Mol Biol 46:15-26.

Pittman M. (1979) Pertussis toxin: the cause of the harmful effects and prolonged immunity of whooping cough. A hypothesis. Rev Infect Dis 1:401-412.

Qadri F, Hasan JA, Hossain J, Chowdhury A, Begum YA, Azim T, Loomis L, Sack RB and Albert MJ. (1995) Evaluation of the monoclonal antibody-based kit Bengal SMART for rapid detection of Vibrio cholerae O139 synonym Bengal in stool samples. J Clin Microbiol 33:732-734.

Raeymaekers L. (1993) Quantitative PCR: theoretical considerations with practical implications. Anal Biochem 214:582-585.

Reizenstein E, Johansson B, Mardin L, Abens J, Möllby R and Hallander HO. (1993) Diagnostic evaluation of polymerase chain reaction discriminative for Bordetella pertussis, B. parapertussis, and $B$. bronchiseptica. Diagn Microbiol Infect Dis 17:185-191.

Reizenstein E, Lindberg L, Möllby R and Hallander HO. (1996) Validation of nested Bordetella PCR in pertussis vaccine trial. J Clin Microbiol 34:810-815.

Relman DA. (1993) The identification of uncultured microbial pathogens. J Infect Dis 168:1-8.

Ririe KM, Rasmussen RP and Wittwer CT. (1997) Product differentiation by analysis of DNA melting curves during the polymerase chain reaction. Anal Biochem 245:154-160.

Ronaghi M, Uhlén M and Nyrén P. (1998) A sequencing method based on real-time pyrophosphate. Science 281:363, 365 .

Rossney AS, Coleman DC and Keane CT. (1994) Antibiogram-resistogram typing scheme for methicillinresistant Staphylococcus aureus. J Med Microbiol 41:430-440.

Ryan D, Nuccie B and Arvan D. (1999) Non-PCR-dependent detection of the factor V Leiden mutation from genomic DNA using a homogeneous invader microtiter plate assay. Mol Diagn 4:135-144.

Saiki RK, Scharf S, Faloona F, Mullis KB, Horn GT, Erlich HA and Arnheim N. (1985) Enzymatic amplification of beta-globin genomic sequences and restriction site analysis for diagnosis of sickle cell anemia. Science 230:1350-1354.

Saiki RK, Walsh PS, Levenson CH and Erlich HA. (1989) Genetic analysis of amplified DNA with immobilized sequence-specific oligonucleotide probes. Proc Natl Acad Sci U S A 86:6230-6234.

Salo WL, Aufderheide AC, Buikstra J and Holcomb TA. (1994) Identification of Mycobacterium tuberculosis DNA in a pre-Columbian Peruvian mummy. Proc Natl Acad Sci U S A 91:2091-2094.

Sanchez-Pescador R, Stempien MS and Urdea MS. (1988) Rapid chemiluminescent nucleic acid assays for detection of TEM-1 beta- lactamase-mediated penicillin resistance in Neisseria gonorrhoeae and other bacteria. J Clin Microbiol 26:1934-1938.

Sanger F, Nicklen S and Coulson AR. (1977) DNA sequencing with chain-terminating inhibitors. Proc Natl Acad Sci U S A 74:5463-5467.

Sayada C, Denamur E, Orfila J, Catalan F and Elion J. (1991) Rapid genotyping of the Chlamydia trachomatis major outer membrane protein by the polymerase chain reaction. FEMS Microbiol Lett 67:73-78. 


\section{NYGREN}

Schena M, Heller RA, Theriault TP, Konrad K, Lachenmeier E and Davis RW. (1998) Microarrays: biotechnology's discovery platform for functional genomics. Trends Biotechnol 16:301-306.

Schena M, Shalon D, Davis RW and Brown PO. (1995) Quantitative monitoring of gene expression patterns with a complementary DNA microarray. Science 270:467-470.

Schmitt-Grohe S, Cherry JD, Heininger U, Uberall MA, Pineda E and Stehr K. (1995) Pertussis in German adults. Clin Infect Dis 21:860-866.

Schwartz HE, Ulfelder K, Sunzeri FJ, Busch MP and Brownlee RG. (1991) Analysis of DNA restriction fragments and polymerase chain reaction products towards detection of the AIDS (HIV-1) virus in blood. J Chromatogr 559:267-283.

Selander RK, Caugant DA, Ochman H, Musser JM, Gilmour MN and Whittam TS. (1986) Methods of multilocus enzyme electrophoresis for bacterial population genetics and systematics. Appl Environ Microbiol 51:873-884.

Sestini R, Orlando C, Zentilin L, Lami D, Gelmini S, Pinzani P, Giacca M and Pazzagli M. (1995) Gene amplification for c-erbB-2, c-myc, epidermal growth factor receptor, int-2, and N-myc measured by quantitative PCR with a multiple competitor template. Clin Chem 41:826-832.

Sharma C, Ghosh A, Ghosh RK, Mukhopadhyay AK and Nair GB. (1998) Molecular analysis of the cholera toxin gene \& antibiotic sensitivity profile of Vibrio cholerae O1 \& O139 associated with mixed infection. Indian J Med Res 107:199-203.

Shumaker JM, Metspalu A and Caskey CT. (1996) Mutation detection by solid phase primer extension. Hum Mutat 7:346-354.

Siebert PD and Larrick JW. (1992) Competitive PCR. Nature 359:557-558.

Smith GJ, 3rd, Helf M, Nesbet C, Betita HA, Meek J and Ferré F. (1999) Fast and accurate method for quantitating E. coli host-cell DNA contamination in plasmid DNA preparations. Biotechniques 26:518-522, 524, 526 .

Souazé F, Ntodou-Thome A, Tran CY, Rostene W and Forgez P. (1996) Quantitative RT-PCR: limits and accuracy. Biotechniques 21:280-285.

Stefanelli P, Giuliano M, Bottone M, Spigaglia P and Mastrantonio P. (1996) Polymerase chain reaction for the identification of Bordetella pertussis and Bordetella parapertussis. Diagn Microbiol Infect Dis 24:197-200.

Stroeher UH, Parasivam G, Dredge BK and Manning PA. (1997) Novel Vibrio cholerae O139 genes involved in lipopolysaccharide biosynthesis. J Bacteriol 179:2740-2747.

Sykes PJ, Neoh SH, Brisco MJ, Hughes E, Condon J and Morley AA. (1992) Quantitation of targets for PCR by use of limiting dilution. Biotechniques 13:444-449.

Syvänen AC, Aalto-Setala K, Harju L, Kontula K and Söderlund H. (1990) A primer-guided nucleotide incorporation assay in the genotyping of apolipoprotein E. Genomics 8:684-692.

Tarnuzzer RW, Macauley SP, Farmerie WG, Caballero S, Ghassemifar MR, Anderson JT, Robinson CP, Grant MB, Humphreys-Beher MG, Franzen L, Peck AB and Schultz GS. (1996) Competitive RNA templates for detection and quantitation of growth factors, cytokines, extracellular matrix components and matrix metalloproteinases by RT-PCR. Biotechniques 20:670-674. 
Tenover FC, Arbeit RD, Goering RV, Mickelsen PA, Murray BE, Persing DH and Swaminathan B. (1995) Interpreting chromosomal DNA restriction patterns produced by pulsed- field gel electrophoresis: criteria for bacterial strain typing. J Clin Microbiol 33:2233-2239.

Tenover FC, Huang MB, Rasheed JK and Persing DH. (1994) Development of PCR assays to detect ampicillin resistance genes in cerebrospinal fluid samples containing Haemophilus influenzae. $\boldsymbol{J}$ Clin Microbiol 32:2729-2737.

Trollfors B, Taranger J, Lagergård T, Lind L, Sundh V, Zackrisson G, Lowe CU, Blackwelder W and Robbins JB. (1995) A placebo-controlled trial of a pertussis-toxoid vaccine. $N$ Engl J Med 333:1045-1050.

Tyagi S, Bratu DP and Kramer FR. (1998) Multicolor molecular beacons for allele discrimination. Nat Biotechnol 16:49-53.

Tyagi S and Kramer FR. (1996) Molecular beacons: probes that fluoresce upon hybridization. Nat Biotechnol 14:303-308.

Uehara H, Nardone G, Nazarenko I and Hohman RJ. (1999) Detection of telomerase activity utilizing energy transfer primers: comparison with gel- and ELISA-based detection. Biotechniques 26:552558 .

Urdea MS, Horn T, Fultz TJ, Anderson M, Running JA, Hamren S, Ahle D and Chang CA. (1991) Branched DNA amplification multimers for the sensitive, direct detection of human hepatitis viruses. Nucleic Acids Symp Ser 197-200.

van der Zee A, Agterberg C, Peeters M, Schellekens J and Mooi FR. (1993) Polymerase chain reaction assay for pertussis: simultaneous detection and discrimination of Bordetella pertussis and Bordetella parapertussis. J Clin Microbiol 31:2134-2140.

Vener T, Axelsson M, Albert J, Uhlén M and Lundeberg J. (1996) Quantification of HIV-1 using multiple competitors in a single-tube assay. Biotechniques 21:248-252, 253-245.

Verma $\mathrm{N}$ and Reeves P. (1989) Identification and sequence of $\mathrm{rfbS}$ and $\mathrm{rfbE}$, which determine antigenic specificity of group A and group D salmonellae. J Bacteriol 171:5694-5701.

Wagener C. (1997) Molecular diagnostics. J Mol Med 75:728-744.

Wahlberg J, Lundeberg J, Hultman T and Uhlén M. (1990) General colorimetric method for DNA diagnostics allowing direct solid-phase genomic sequencing of the positive samples. Proc Natl Acad Sci U S A 87:6569-6573.

Waldor MK and Mekalanos JJ. (1994) Emergence of a new cholera pandemic: molecular analysis of virulence determinants in Vibrio cholerae $\mathrm{O} 139$ and development of a live vaccine prototype. $\boldsymbol{J}$ Infect Dis 170:278-283.

Walker GT, Fraiser MS, Schram JL, Little MC, Nadeau JG and Malinowski DP. (1992) Strand displacement amplification-an isothermal, in vitro DNA amplification technique. Nucleic Acids Res 20:1691-1696.

Wang AM, Doyle MV and Mark DF. (1989) Quantitation of mRNA by the polymerase chain reaction [published erratum appears in Proc Natl Acad Sci U S A 1990 Apr;87(7):2865]. Proc Natl Acad Sci U S A 86:9717-9721.

Wang DG, Fan JB, Siao CJ, Berno A, Young P, Sapolsky R, Ghandour G, Perkins N, Winchester E, Spencer J, Kruglyak L, Stein L, Hsie L, Topaloglou T, Hubbell E, Robinson E, Mittmann M, Morris MS, Shen N, Kilburn D, Rioux J, Nusbaum C, Rozen S, Hudson TJ, Lander ES and et al. (1998) 


\section{NYGREN}

Large-scale identification, mapping, and genotyping of single- nucleotide polymorphisms in the human genome. Science 280:1077-1082.

Wei X, Ghosh SK, Taylor ME, Johnson VA, Emini EA, Deutsch P, Lifson JD, Bonhoeffer S, Nowak MA, Hahn BH and et al. (1995) Viral dynamics in human immunodeficiency virus type 1 infection. Nature 373:117-122.

Welsh J and McClelland M. (1990) Fingerprinting genomes using PCR with arbitrary primers. Nucleic Acids Res 18:7213-7218.

Whitcombe D, Theaker J, Guy SP, Brown T and Little S. (1999) Detection of PCR products using selfprobing amplicons and fluorescence. Nat Biotechnol 17:804-807.

WHO. WHO meeting on case definition of pertussis. 1991. World Health Organization, Geneva.

Williams JG, Kubelik AR, Livak KJ, Rafalski JA and Tingey SV. (1990) DNA polymorphisms amplified by arbitrary primers are useful as genetic markers. Nucleic Acids Res 18:6531-6535.

Wilson KH. (1994) Detection of culture-resistant bacterial pathogens by amplification and sequencing of ribosomal DNA. Clin Infect Dis 18:958-962.

Wittwer CT, Fillmore GC and Garling DJ. (1990) Minimizing the time required for DNA amplification by efficient heat transfer to small samples. Anal Biochem 186:328-331.

Wittwer CT, Herrmann MG, Moss AA and Rasmussen RP. (1997) Continuous fluorescence monitoring of rapid cycle DNA amplification. Biotechniques 22:130-131, 134-138.

Wolff JA, Ludtke JJ, Acsadi G, Williams P and Jani A. (1992) Long-term persistence of plasmid DNA and foreign gene expression in mouse muscle. Hum Mol Genet 1:363-369.

Woolley AT, Hadley D, Landre P, deMello AJ, Mathies RA and Northrup MA. (1996) Functional integration of PCR amplification and capillary electrophoresis in a microfabricated DNA analysis device. Anal Chem 68:4081-4086.

Wu DY, Ugozzoli L, Pal BK and Wallace RB. (1989) Allele-specific enzymatic amplification of betaglobin genomic DNA for diagnosis of sickle cell anemia. Proc Natl Acad Sci U S A 86:2757-2760.

Wu DY and Wallace RB. (1989) The ligation amplification reaction (LAR)-amplification of specific DNA sequences using sequential rounds of template-dependent ligation. Genomics 4:560-569.

Yang JQ, Tata PV, Park-Turkel HS and Waksal HW. (1991) The application of AmpliProbe in diagnostics. Biotechniques 11:392-397.

Young KK, Resnick RM and Myers TW. (1993) Detection of hepatitis C virus RNA by a combined reverse transcription- polymerase chain reaction assay. J Clin Microbiol 31:882-886.

Zimmermann K $a$ and Mannhalter JW. (1996) Technical aspects of quantitative competitive PCR. Biotechniques 21:268-272, 274-269.

Zimmermann K $b$, Schogl D, Plaimauer B and Mannhalter JW. (1996) Quantitative multiple competitive PCR of HIV-1 DNA in a single reaction tube. Biotechniques 21:480-484.

zur Hausen H. (1977) Human papillomaviruses and their possible role in squamous cell carcinomas. Curr Top Microbiol Immunol 78:1-30.• 